\title{
Imaging of Endocytosis in Paramecium by Confocal Microscopy
}

\author{
Paola Ramoino, Alberto Diaspro, Marco Fato and Cesare Usai
}

Additional information is available at the end of the chapter

http://dx.doi.org/10.5772/46061

\section{Introduction}

Endocytosis is the general term for internalization of fluid, solutes, macromolecules, plasma membrane components, and particles by the invagination of the plasma membrane and the formation of vesicles and vacuoles through membrane fusion. The means by which food material enters the body is to a great extent dependent on the size of the particles involved $[1,2]$. One type of endocytosis is phagocytosis where large $(>250 \mathrm{~nm})$ particles are taken up by cells. In protozoa, phagocytosis is a feeding mechanism. Particles are brought into the cell in large endocytic vesicles called phagosomes (food vacuoles). The phagosomes fuse with lysosomes and digestion of the ingested particles occurs. In multicellular organisms, phagocytosis is a behavior seen only in certain specialized cells (for example, macrophages). The process is essentially the same whether it is phagocytosis of particles or other organisms or pinocytosis of molecules. Both endocytic processes are affected identically by inhibitors of aerobic metabolism and by low temperatures.

The various forms of endocytosis (or food uptake) really only differ in degree. They are closely linked in that the combined volume taken up by endocytosis is constant and critical. As phagocytosis increases, pinocytosis must decrease proportionally. In addition to the forms of bulk transport just considered, which involve invagination of the plasma membrane, other essential substances, dissolved nutrients of low molecular weight, enter the organism by facilitated diffusion or active transport through the plasma membrane.

Some protozoa secrete hydrolyzing enzymes into the external medium to degrade large nutritive molecules into smaller soluble units for transport through the plasma membrane. This facility for extracellular digestion is of value to facultative and obligate parasites and to other protozoa which live in a highly nutritive environment. 
Ciliated protozoa collect or capture their food in a variety of ways, involving phagocytosis, fluid phase and receptor-mediated endocytosis

\section{Phagocytosis}

\subsection{Phagocytosis in ciliates}

Ciliates acquire their food as particles from the surrounding medium by a variety of means [1-5]. Filter feeders create water currents with special ciliary structures associated with the cytostome. The synchronized beating of these membranelles acts as a collecting sieve, where the food particles become trapped. Using this mode of feeding, ciliates can shift considerable volumes of water in relation to their size. Some of the most efficient filter feeders are the hymenostomes Paramecium, Tetrahymena and Glaucoma. All have a ventral buccal (oral) cavity containing well-developed ciliary membranelles and some form of paroral membrane on its right margin. Fluid and suspended food particles are collected in the buccal cavity and directed, by oral membranelle beating, downward to the cytopharynx and cytostome to form a new food vacuole $[6,7]$.

Herbivorous ciliates, instead, lack complex oral cilia and gather their food by a complex pharyngeal basket of rods and sheets of microtubules that forms an internal support to the cytostome. They ingest filamentous algae by grasping the filament, bending it like a hairpin, and drawing it into the cytopharynx, where it is broken up into fragments and enclosed in digestive vacuoles.

Gulper ciliates apprehend their prey with special structures called toxicysts, which are found in the oral region and release toxins that paralyze or kill the swimming prey organims. The paralyzed prey can then be ingested without difficulty. Indeed the oral area of gulpers can be extended greatly, as most carnivores take food at least as big as themselves. The initial contact may be due to chemotactic orientation or fortuitous contact. Some ciliates develop carnivorous tendencies only when their preferred food supply is exhausted. In the absence of bacteria Blepharisma eats its own kind and develops giant forms for self-protection [8].

Sophisticated organelles involved in ingestion are tentacles of suctoria. The predatory or parasitic suctorians are sessile ciliates. The ectocommensals on a wide variety of marine and freshwater hosts use the motile activities of their host or its feeding strategy to bring food to them. Carnivores have developed a special method of feeding in which the tips of the tentacles act as cytostomes. The contact between the prey and the tentacles of the predator triggers the stimulus for ingestion. The cell contents of the prey are transported up through the feeding tentacles into the suctorian, where digestive vacuoles are formed. The transporting mechanism is mediated by a complex array of microtubules within the tentacle.

A number of ciliates respond to exudates from animal tissues and have exploited this response by becoming active scavengers. Sheet-like membranous organelles associated with feeding are a feature of apostome ciliates which live in or on a variety of animal hosts, arthropods, echinoderms and sea anemones. 


\subsection{Paramecium as a model system for membrane trafficking}

The ciliated protozoan Paramecium is easily cultured and manipulated. Therefore, it is especially useful to study in vivo vesicle formation, transport and fusion during the digestive process. It disposes of well-defined sites for formation of phagosomes (oral cavity, with cytostome and cytopharynx) $[9,10]$.

Food vacuoles undergo a series of sequential changes from their formation at the cytostome to their defecation at the cytoproct. Depending on their age, size, morphology, vacuolar $\mathrm{pH}$, acid phosphatase activity and degree of bacteria digestion, they have been grouped into four stages [11-17].

The first stage, stage I, includes the nascent and newly formed food vacuoles which separate from the base of the cytopharynx and move toward the posterior end of the cell (Figure 1). During stage I, food vacuoles have no acid phosphatase activity and are bounded by acidosomes. Their content condenses, becoming progressively more acidic, and surplus vacuolar membrane and excess fluid are removed by pinocytosis of vesicles which migrate back to the cytopharynx. The condensed and acidic food vacuoles (stage II) are surrounded by enzyme-containing primary lysosomes. As lysosomes fuse and digestion proceeds, the vacuole enlarges again, becoming less acidic or even slightly alkaline (stage III). The breakdown products are pinched off as small vesicles (secondary lysosomes) to be transported where necessary. Following membrane and water elimination, the food vacuole decreases in size and tends to a neutral $\mathrm{pH}$ (stage IV); the active retrieval of lysosomal membrane may continue during this stage, but active acid phosphatase is not present. In the final stage, when the food vacuole becomes defecation-competent, it fuses with the plasma membrane at the cytoproct (a fixed spot on the ventral surface, posterior to the buccal cavity). The indigestible material is excreted, while the vacuolar membrane is retrieved and recycled as discoidal vesicles moving back to cytopharynx and providing the membrane to the nascent food vacuole.

\subsection{Phagocytosis in Paramecium by confocal microscopy}

In paramecia fed with indigestible particles, the duration of the digestive cycle is relatively short (20 to 60 minutes), and the digestive processes are synchronous enough and so temporally defined as to allow food vacuole selection in a specific digestion stage using a pulse-chase protocol. By immobilizing living cells pulsed with a food vacuole marker at succeeding times after a chase of unlabeled medium, it is possible visualize in vivo the intracellular movement of food vacuoles along an orderly path from their formation at the cytostome to their egestion at the cytoproct, as well as the flow of pinocytic vesicles from vacuolar membrane evagination to the fusion with other food vacuoles.

The sequence of appearance of the four vacuole stages in different regions of the cell follows the general path of cyclosis and indicates that the cytoplasm moves forward in the dorsal zone and backward in the ventral zone $[6,18]$. Notwithstanding the fact that the digestive processes are sufficiently synchronous and separated in time, there is considerable overlap 
and variability in the length of the food vacuole stages from cell to cell, and possibly from food vacuole to food vacuole [16]. Food vacuoles less than 5 min old are vacuoles of stage I located in the posterior end of the cell and undergoing rapid acidification and condensation. Vacuoles between 5 to $10 \mathrm{~min}$ old are acidic and condensed food vacuoles of stage II; they are located near the oral region and around the macronucleus. The vacuoles of stage III range in age from 10 to about $20 \mathrm{~min}$ and are generally located in the anterior half of the cell, while stage IV food vacuoles are more than $21 \mathrm{~min}$ old and move toward the cytoproct. Vacuolar defecation has been shown to begin at about $20 \mathrm{~min}$ and is essentially completed by $60 \mathrm{~min}$ in axenically grown cells [14] as well as in bacterized cells.

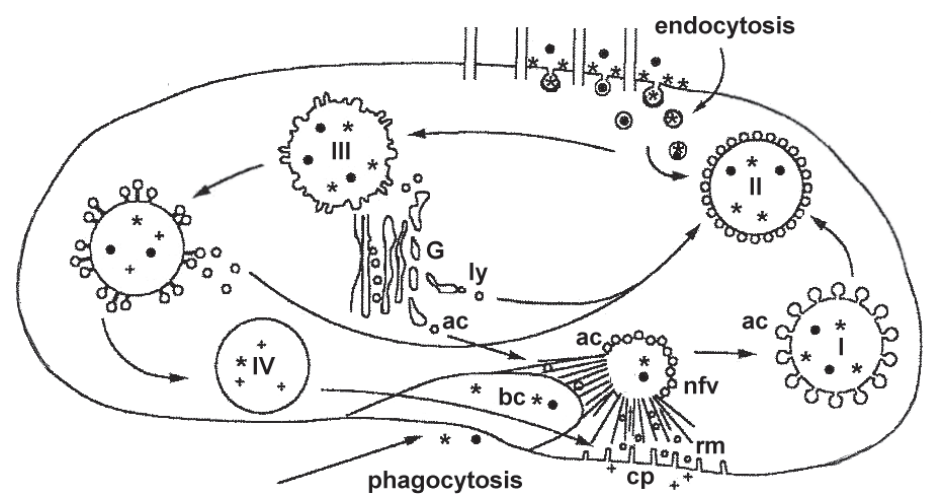

Figure 1. Schematic drawing of phagocytic and endocytic pathways of internalization in Paramecium based upon WGA-FITC and dextran-TXR staining. Without phagocytosis inhibition the ingested material is directed by the oral membranelle beating into the buccal cavity $(\mathrm{bc})$, the cytopharynx and, at last, into the nascent food vacuole (nfv). The newly formed food vacuole (I) is surrounded by acidosomes (ac) discharging their content into it. The vacuole reduces its size by eliminating water and membrane trough small pinocytic vesicles. The condensed vacuole (II) receives the enzymes contained into lysosomes (ly). The cargo is digested (III) and pinocytic vesicles containing digestion products are pinched off. At last, the indigestible material (IV) is excreted at the cytoproct (cp), while the vacuolar membrane is retrieved ( $\mathrm{rm}$ ). The endocytosis of WGA-FITC and dextran-TXR also occurs at the parasomal sacs located next the ciliar basal bodies. Exogenous fluid and plasma membrane components are internalized by vesicles which fuse with food vacuoles. $G=$ Golgi apparatus; ${ }^{*}=$ WGA-FTC; ${ }^{\circ}=$ dextran-TXR; $+=$ degraded material; $\leftrightarrow$ = flow direction (modified from Allen et al. [17]).

In order to characterize the cytoplasmic distribution and movement of food vacuoles and pynocytic vesicles, living cells were continuously fed with BSA-FITC and latex particles (LP) in culture medium for a time period ranging from $30 \mathrm{sec}$ to $30 \mathrm{~min}$, washed, immobilized with $\mathrm{NiCl}_{2}$ [19]. $\mathrm{NiCl}_{2}$ inhibits both locomotive activity [20] and formation of food vacuoles with solid particle content [21], without affecting cytoplasmic streaming [21]. To demonstrate the reutilization of pinocytic vesicles and vesicles formed by the membrane retrieved from spent vacuoles at the cytoproct, cells first fed with BSA-FITC and LP for 30 $\mathrm{min}$, then washed in sterile filtered culture medium for 20 to $30 \mathrm{~min}$, were labeled with carmine particles or BSA-Texas red for $1 \mathrm{~min}$, washed and immobilized at various times during chase [19]. 

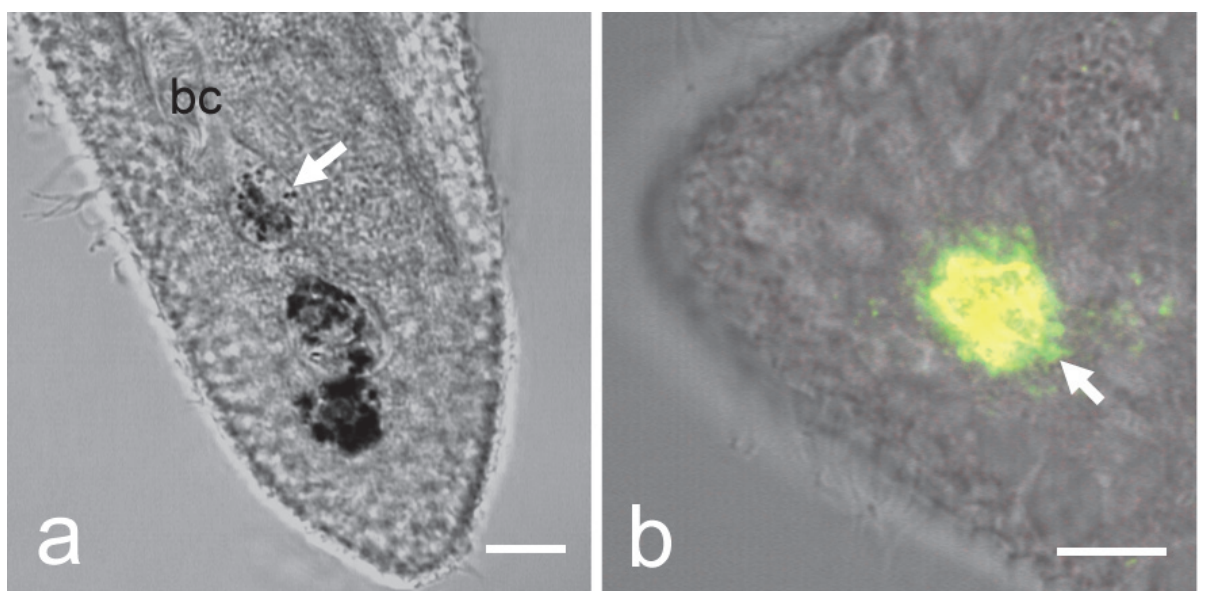

Figure 2. (a) One nascent food vacuole (arrow) at the bottom of buccal cavity (bc) and two newly formed food vacuole in a cell fed (carmine particles). (b) In cells fed with BSA-TXR, newly formed food vacuoles which fused with BSA-FITC labeled recycled vesicles (arrow), contain both fluorochromes.

Bars, $10 \mu \mathrm{m}$.

In cells fed with carmine particles for $30 \mathrm{sec}$, only 1-2 food vacuoles are labeled (Figure 2a). To enlarge the membrane surrounding the nascent food vacuoles, cells utilize recycled vesicles that are pinched off from food vacuoles during the digestive process and the vesicles deriving from the membrane of the spent vacuoles at the cytoproct. So, in cells fed with BSA-Texas red newly formed food vacuoles, which fused with BSA-FITC labeled recycled vesicles, contain both fluorochromes (Figure $2 b$ ). Food vacuoles separating from the cytopharynx and moving toward the posterior end of the cell, are surrounded by small acidic vesicles (acidosomes) and by lysosomes (containing hydrolytic enzymes) which fuse with vacuolar membrane. To analyze the distribution of acidosomes and lysosomes during food vacuole migration, living cells pulsed with LP for 1-2 min, were labeled with acridine orange $(\mathrm{AO})$ at various times after the chase in unlabeled medium, and immobilized. $\mathrm{AO}$ is a fluorescent tertiary amine that accumulates in the acidic compartment of living cells and is commonly used to stain lysosomes [23-25]. The fluorescence around the newly formed food vacuoles $(<5 \mathrm{~min}$ old $)$ is due to acidosomes [25], whereas the fluorescence around and within $>5$ min-old food vacuoles is due to lysosomes. The AO-stained granules produce a punctuate pattern throughout the cell and around certain food vacuoles. Fluorescent granules, including both primary and secondary lysosomes, form a relatively thin rim around 6 min-old food vacuoles containing LP (Figure 3a). The rim becomes quite prominent in other food vacuoles (10 min old), as the lysosomes fuse with the vacuolar membrane and discharge their content into the vacuole (Figure $3 b$ ). 

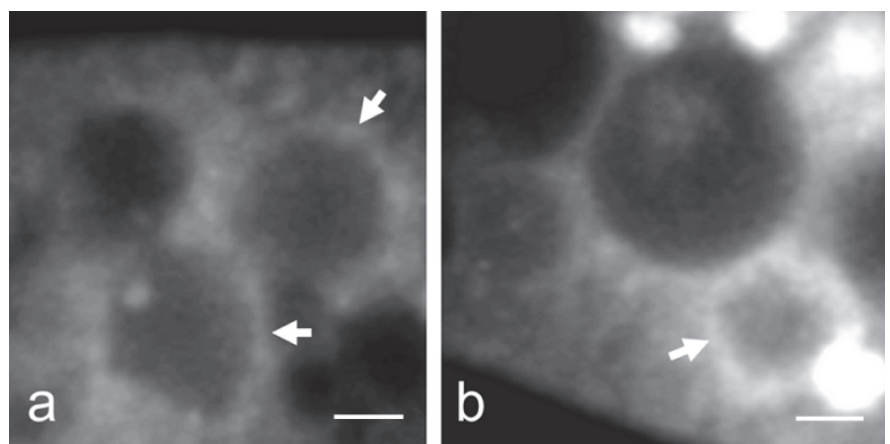

Figure 3. (a) Stage II LP-labeled food vacuoles (non-fluorescent) surrounded by AO-labeled lysosomes (arrows). (b) Stage III LP-labeled food vacuole (more fluorescent in the surface area, arrow): AO-labeled lysosomes are fusing and discharging their content into the vacuole. Bars, $10 \mu \mathrm{m}$.(modified from Ramoino et al. [19])

As the vacuolar content is digested by lysosomal enzymes, the breakdown substances pass into the cytoplasm through vacuolar membrane or by way of small pinocytic vesicles. The vesicles evaginated from the membrane, go away from the food vacuole and move in the cytoplasm toward the cytopharynx where they enlarge the membrane of the nascent food vacuole. These vesicles can also fuse with stage II food vacuoles (Figure 4), when the vacuoles of stage II increase their size, changing from an acidic to an alkaline status. For better visualization of the movement of the pinocytic vesicles, cells are fed with BSA-FITC and LP for 30 sec. and washed in a sterile culture medium. So, only 1 or 2 labeled vacuoles are formed and few fluorescent vesicles move in the cytoplasm. When the cells are immobilized between 15 to $20 \mathrm{~min}$ after chase in sterile medium, the food vacuoles are in the digestion stage and small pinocytic fluorescent vesicles pinch off. The multimodal image analysis utilizing the pseudo-color technique [26] shows changes on the direction of movement of the vesicles going away from the vacuole (Figure 5a).
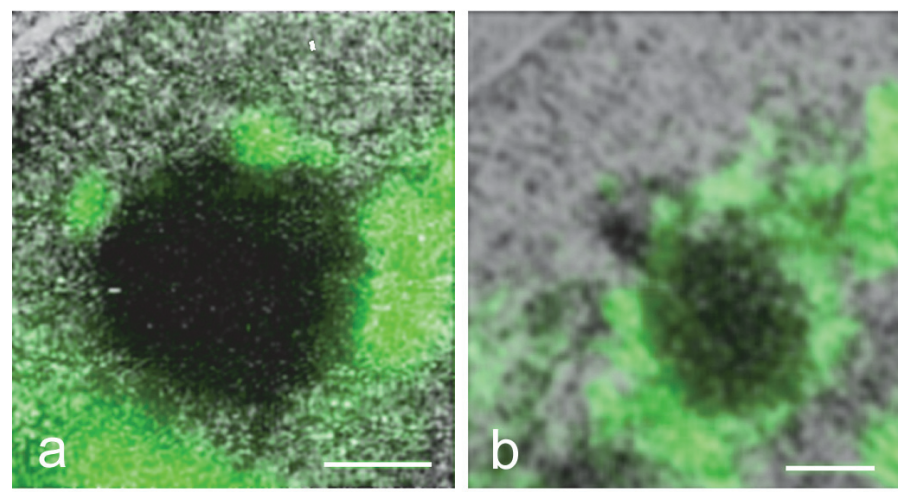

Figure 4. (a) Carmine-labeled food vacuole (non-fluorescent) surrounded by FITC- labeled fluorescent vesicles. Carmine-labeled food vacuole (more fluorescent in the superficial zone) surrounded by FITClabeled fluorescent vesicles. Bars, $5 \mu \mathrm{m}$ (modified from Ramoino et al. [19]) 
The utilization of recycled vesicles from stage II and early stage III food vacuoles is evidenced by labeling food vacuoles either with carmine particles or with a second fluorescent probe. When carmine particles are utilized, food vacuoles in cells immobilized after a 5-min. chase (stage II) are initially non-fluorescent and surrounded with a lot of fluorescent small vesicles (Figure 4a), then, as the vesicles fuse with the food vacuole (stage III), their content becomes fluorescent. At the beginning fluorescence is only located in the surface area (Figure $4 \mathrm{~b}$ ), then, it increases as the food vacuole age progresses and more vesicles fuse discharging their labeled content inside the vacuole. Vesicles, which fuse with food vacuoles, move apparently in unidirectional manner (Figure 5b).
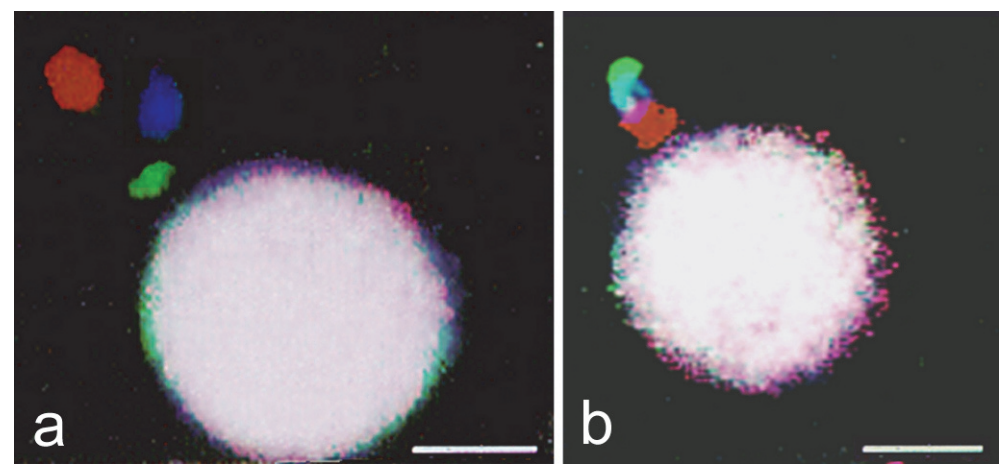

Figure 5. Composite false-color images showing the global vesicle movement of one FITC-labeled vesicle moving away from a food vacuole (a) as well as of one small FlTC-labeled vesicle moving toward the vacuole (b). A different color, green, blue and red, was associated with three successive temporal images $t_{1}, t_{2}, t_{3}$, respectively. Bar, $10 \mu \mathrm{m}$. (modified from Ramoino et al. [19])

In Paramecium, a saltatory movement with changes in direction and velocity, stops and starts, was described for cell organelles such as mitochondria and trichocysts in subcortical regions of the cell [27] and for all motions within the cytoplasmic streaming [28], whereas a smooth and continuous unidirectional movement along the microtubules joined to the cytopharynx was reported for acidosomes and discoidal vesicles [29].

After a digestion period, the food vacuole becomes defecation-competent and fuses with plasma membrane; the indigestible material is excreted. Figure 6 is a composite picture of phase-contrast CLSM images demonstrating the temporal and spatial movement and egestion of food vacuoles at the cytoproct.

In $P$. primaurelia food vacuole formation depends on membrane material supply [30]. By using different solid particle concentrations in unbacterized culture medium it is shown that a given amount of membrane material is available for food vacuole formation. This membrane amount is utilized more rapidly if the concentration of particles is higher, where the food vacuole size is larger, than for a lower concentration, where the food vacuole size is smaller. After the utilization of the membrane made available for the cell, a decrease in the food vacuole number occurs. Furthermore, the rate of food ingestion decreases in starved cells pressed continuously to form food vacuoles because of particles suspended in the 
culture medium. The kinetics of food vacuole formation does not differ when cells are fed on latex particles in bacterized and unbacterized medium for short periods of time. For longer labeling periods with high particle concentrations, the food vacuole number decreases after the maximum value more rapidly in cells stained with particles in nonnutrient medium than in cells fed with particles diluted in bacterized medium. The spent vacuole membrane is insufficient to keep the food vacuole number at a high level. Failing new syntheses, the vacuolar membrane amount goes on depressing.

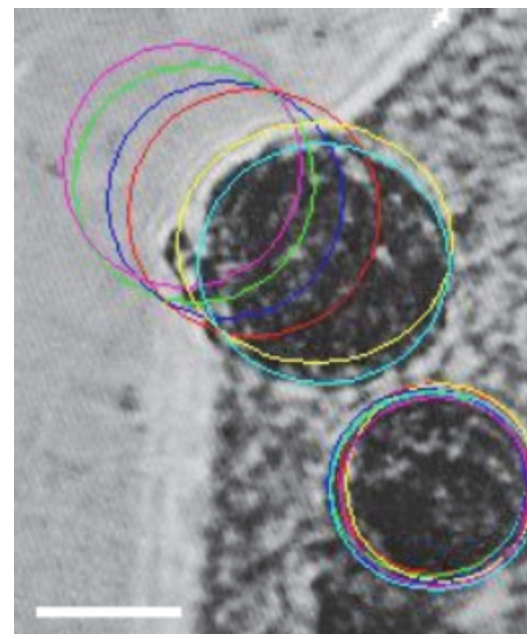

Figure 6. Composite image showing the movement of a food vacuole egesting its content at the cytoproct. A different color cyan, yellow, red, blue, green and magenta was associated with six successive temporal images $\mathrm{t}_{1}, \mathrm{t}_{2}, \mathrm{t}_{3}, \mathrm{t}_{4}, \mathrm{t}_{5}$ and $\mathrm{t}_{6}$, respectively. Bar, $10 \mu \mathrm{m}$.

\section{Endocytosis}

\subsection{Endocytosis in ciliates}

Fluid phase and receptor-mediated endocytosis has been extensively studied in mammalian cells [31-34] and most of what is understood about the endocytic process in protozoa comes from the studies of pinocytosis in amoeba [35-37]. In an amoeba pinocytotic vesicles are formed at the bases of long narrow invaginations, pinocytotic channels. Small vesicles are pinched off at the base of a channel deep in the cytoplasm and are passed into the interior. But fluid phase endocytosis does not necessarily involve the development of channels. The parasitic Opalina ranarum, which must take up nutrients through its plasma membrane, pinches off small vesicles in the grooves between the folds in its pellicle [38]. Once inside, vesicles coalesce to form larger vacuoles bounded by unit membranes, vacuoles which are not markedly different from endocytic vacuoles produced by phagocytosis. Fluid phase endocytosis may occur simultaneously all over the surface as in amoebae, or it may be restricted to clearly defined regions, such as the walls of the flagellar pocket of some trypanosomes. 
The limited data about endocytosis in ciliates is also due to the difficulty of visualizing this process at an optical level. Indeed, in ciliates only defined areas on cell surface are potential sites for endocytic uptake since most of the surface is covered internally by an extensive system of alveoli and an underlying fibrous epiplasm [39]. This system is interrupted only at the cytopharynx, the cytoproct, contractile vacuole pores and along the junctions of the abutting units of alveolar membrane sacs. Only the punctuate indentations of the plasma membrane, called parasomal sacs, and pellicular pores are potential endocytic entry ports of all fluid phase and putative receptor-mediated endocytosis [17, 40-42].

Detailed morphological and tracer studies on endocytosis carried out by electron microscopy showed that in Paramecium multimicronucleatum fluid phase markers such as horseradish peroxidase (HRP) and in Tetrahymena pyriformis receptor-mediated markers such as cationized ferritin are internalized via coated pits and are found in coated vesicles $[40,41]$. Both coated pits and vesicles are also labeled in fixed cells when a monoclonal antibody against the plasma membrane of P. multimicronucleatum (C6 antigen) is applied to cryosections, suggesting that both membrane-bound and fluid phase markers are internalized at the coated pits [40]. Most endocytic sites are clathrin coated pits, however there is increasing evidence for mammalian cells for clathrin-independent pathways, mediated by caveolae or non-coated vesicles [43].

In Paramecium the fluorescence amount internalized by endocytosis is less than that internalized by phagocytosis even if an increased endocytic rate is obtained when food vacuole formation is blocked. Indeed, evidence was provided by electron microscopy studies that the number of endocytic vesicles increased when food vacuole formation was blocked by trifluoperazine, a calmodulin antagonist [41]. In addition, by means of a quantitative analysis, it was evidenced more specifically that the HRP influx rate increased twofold when phagocytosis was blocked by propranolol, a $\beta$-adrenergic antagonist [44]. Wyroba [44] suggested that in Paramecium the increased fluid phase uptake indicates that the two pathways, though independent, may be limited by a membrane pool and/or energy requirements. Indeed, forskolin and phorbol ester, powerful stimulants of Paramecium phagocytosis [45], reduce the HRP uptake rate.

\subsection{Endocytosis in Paramecium by confocal microscopy}

Endocytosis in P. primaurelia was studied using WGA (Triticum vulgaris agglutinin) and GАВАв receptor antibodies, which bind to surface constituents of fixed [46, 47] and living cells, as markers for membrane transport and dextran as a marker for fluid phase endocytosis.

Endocytosis markers are internalized via food vacuoles formed at the cytopharynx when they are added to the cell incubation medium without phagocytosis inhibition [48]. Cells pulsed with WGA-FITC for 3 min show some food vacuoles at the posterior pole of the body. After a 10-min chase in unlabeled medium the number of fluorescent food vacuoles increases (data not shown). The increase in labeled food vacuoles in a fluorochrome-free 
medium is due to the fact that the ingested lectins are degraded and pass into the cytoplasm by small vesicles which then fuse with other food vacuoles [19]. Increasing the chase in unlabeled medium increases the fluorescence inside the cytoplasm, which is found later in the vesicles of the phagosome-lysosome system and at the plasma membrane level. Conversely, when phagocytosis is blocked by trifluoperazine, the fluorescence is initially found, in 3 min pulsed cells, on the plasma membrane and cilia and inside the cell into small cytoplasmic vesicles (Figure 7a). After a 5-10 min chase in unlabeled medium, fluorescent vesicles fuse with some food vacuoles (Figure $7 \mathrm{~b}$ ), and after 20-30 $\mathrm{min}$ the labeled food vacuoles increase in number and small vesicles throughout the cytoplasm fluoresce (Figure 7c). Therefore, the digestion inside the vacuoles of lectins internalized via endocytosis begins later with respect to lectins internalized via food vacuole formation (phagocytosis). Moreover, a very weak fluorescence is detectable on plasma membrane after longer time periods compared with lectin internalization via food vacuole formation.

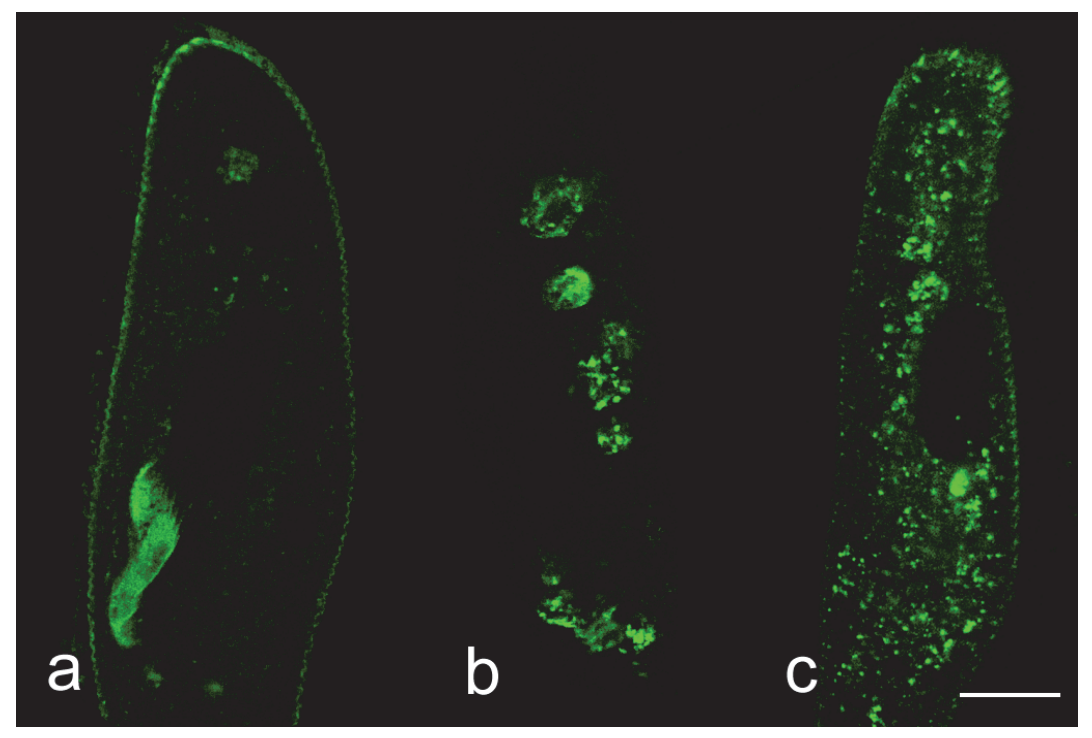

Figure 7. WGA internalization and intracellular flow. Cells labeled with WGA-FITC for 3 min. Plasma membrane and small vesicles inside the cell fluoresce (a). After a 10 min chase in unlabeled medium (b) fluorescence is visible in a few food vacuoles whereas after $30 \mathrm{~min}$ (c) small vesicles throughout the cytoplasm fluoresce. Bar, $20 \mu \mathrm{m}$. 
The fusion of endocytic vesicles with food vacuoles is evidenced by a double-labeling experiment in which the vesicles are dyed with WGA-FITC and the food vacuoles with BSATXR (Figure 8).

Similar results were obtained in cells blocked in the phagocytic activity, incubated at $25^{\circ} \mathrm{C}$ in a culture medium containing an antibody anti-GABAв R1 receptor for 15-30 minutes and then fixed and processed for immunolabeling.

Dextran-TXR, a fluid phase endocytosis marker, does not label the plasma membrane and enters the cell via small vesicles initially localized at the cortical level (Figure 9a). The vesicles later migrate in the cytoplasm and fuse with other endocytic vesicles and with food vacuoles (Figure 9b). The number of labeled food vacuoles increases as the dextran-labeled vesicles fuse with food vacuoles (Figure 9c) and then decreases when the vacuolar content is digested and food vacuoles containing the indigestible material are ejected at the cytoproct.

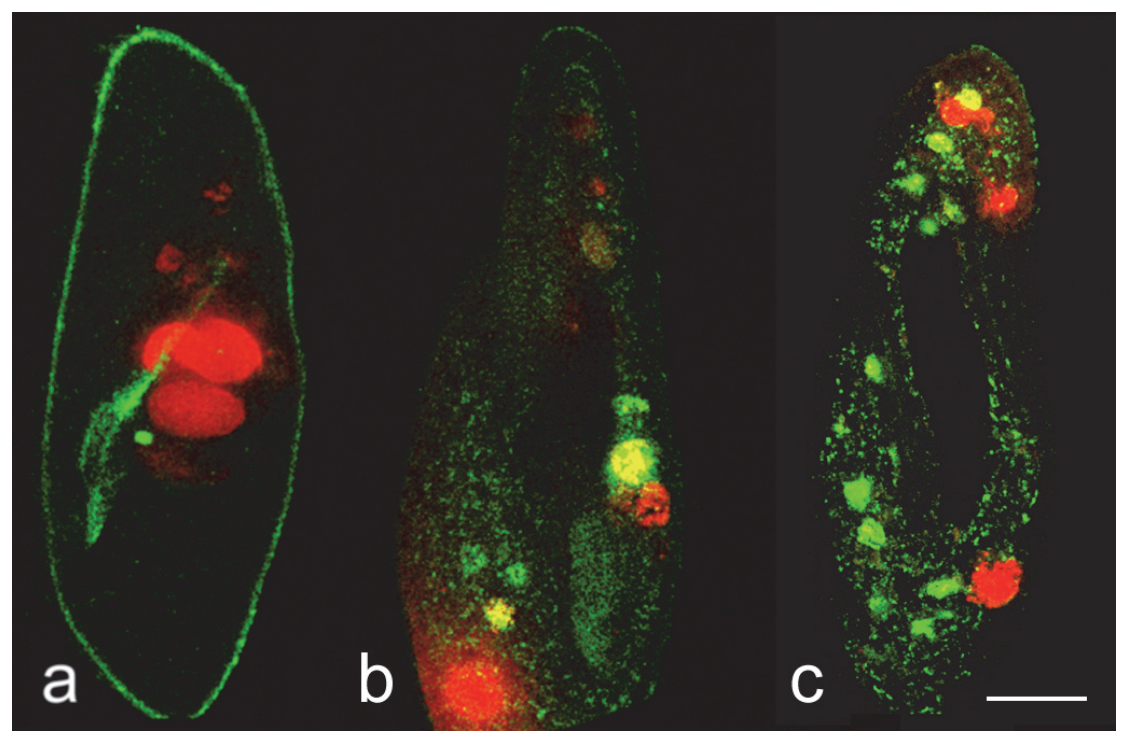

Figure 8. Fusion of endocytic vesicles with food vacuoles. Cells fed with BSA-TXR for $20 \mathrm{~min}$, washed, and labeled with WGA-FITC for $5 \mathrm{~min}$. At first, green fluorescence is localized on plasma membrane (a); after 20 (b) and $30 \mathrm{~min}$ (c) of chase in unlabeled medium green fluorescence is also present inside the food vacuoles. Bar, $20 \mu \mathrm{m}$. 


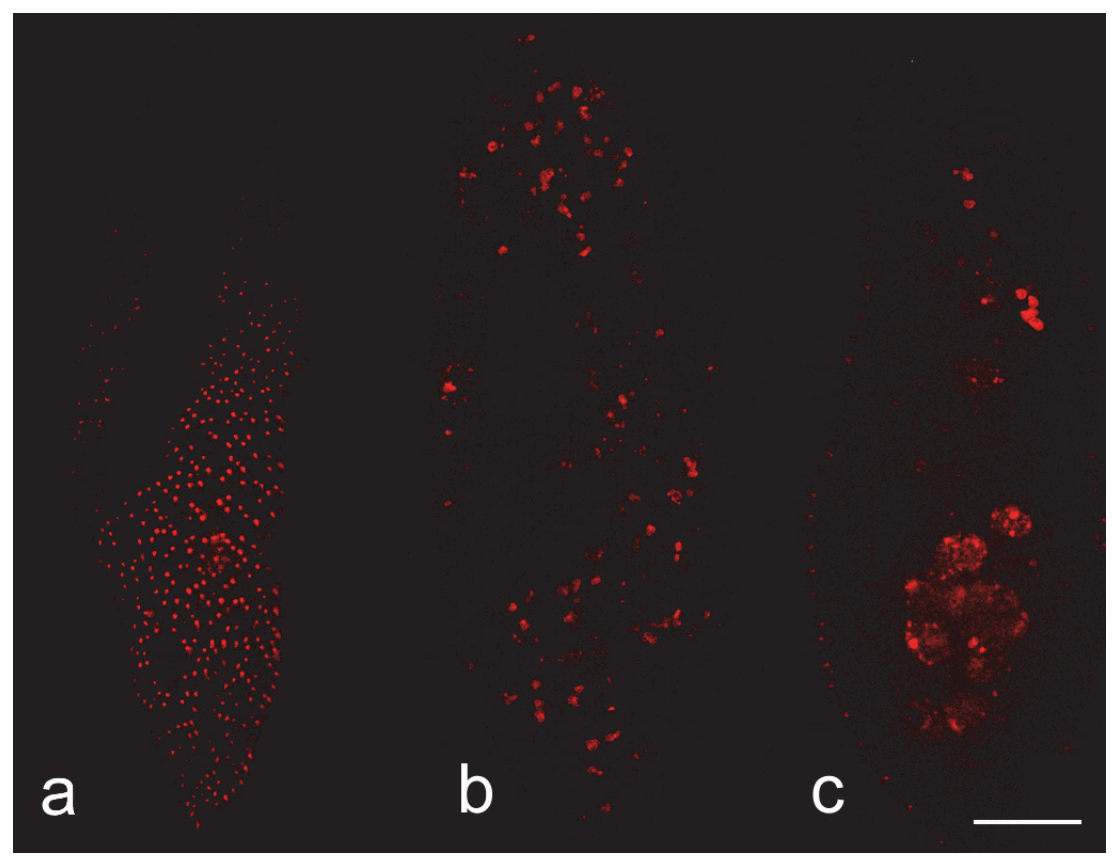

Figure 9. Dextran internalization and intracellular flow. In cells labeled with dextran-TXR for 3 min fluorescence is visible in small vesicles located in the cortex under the plasma membrane (a). After a 10 min chase in unlabeled medium (b), vesicles decrease in number and increase in size. After 30 min several food vacuoles are labeled (c). Bar, $20 \mu \mathrm{m}$.

The relationships between the two different routes of internalization, membrane transport and fluid phase endocytosis, are clearly shown when cells blocked in their phagocytic activity are simultaneously fed with WGA-FITC and dextran-TXR (Figure 10). The data obtained by confocal microscopy suggest that WGA and dextran are present in different endocytic vesicles soon after initiation of uptake (<10 $\mathrm{min})$. The two probes probably partly join prior to their fusion with the phago-lysosomal compartment. From these data we can assume that dextran-TXR and WGA-FITC enter the cells through two different vesicle populations, which then can fuse together or with food vacuoles.

In order to understand if the two markers are internalized through two separate pathways, cells were incubated either in a hypertonic medium or in acetic acid. Indeed, subjecting mammalian cells to either incubation in media containing sucrose [49] or cytosol acidification with acetic acid [50, 51] has been shown to inhibit clathrin-mediated endocytosis by interfering with clathrin-adaptor interactions [52], or by altering the structure of clathrin itself [53-55]. In P. primaurelia $0.20 \mathrm{M}$ sucrose incubation completely blocks the internalization of WGA, which stops at the plasma membrane (Figure 11a). It also reduces dextran uptake, which is localized in small vesicles in the cortical part of the cell and in a few vesicles throughout the cytoplasm. Through cytosol acidification by $10 \mathrm{mM}$ acetic acid, pH 5.0, WGA fluorescence is localized at the plasma membrane level whereas 
small red vesicles containing dextran are localized both in the cortex, under the plasma membrane, and throughout the cytoplasm (Figure 11b). A similar fluorescent pattern was seen by using chlorpromazine (data not shown), a cationic amphiphilic drug which inhibits clathrin-dependent receptor mediated endocytosis by reducing the number of coated pitassociated receptors at the cell surface $[56,57]$.

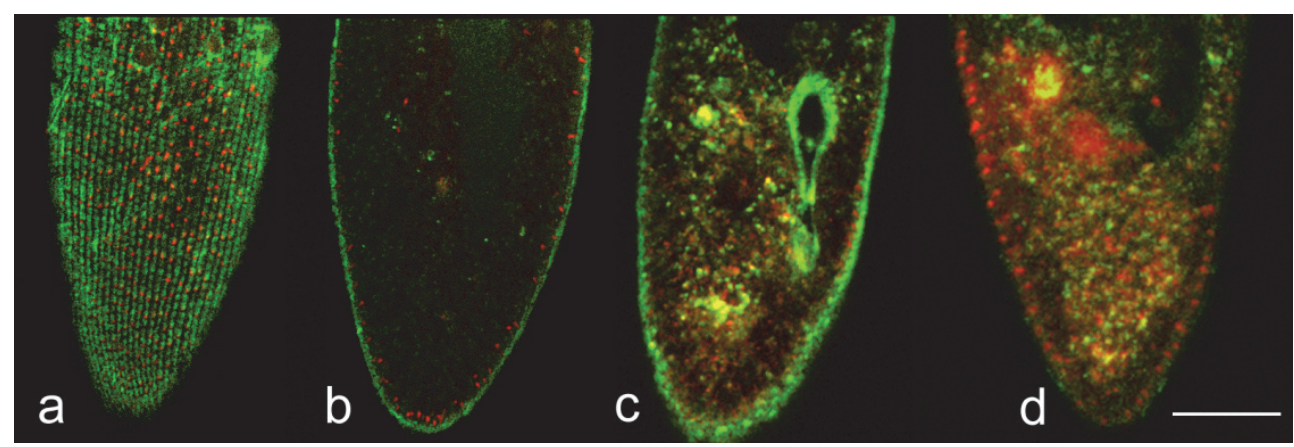

Figure 10. Double labeling with WGA and dextran. Cells are fed with WGA-FITC and dextran-TXR for $5 \mathrm{~min}(\mathrm{a}, \mathrm{b})$, and fixed after 10 (c) and $20 \mathrm{~min}$ (d) of chase in unlabeled medium. (a) and (b) are images of the same cell acquired at different focus planes. WGA and dextran are present in different endocytic vesicles soon after initiation of uptake $(<10 \mathrm{~min})$, then the two probes partly join prior to their fusion with food vacuoles. Bar, $20 \mu \mathrm{m}$.
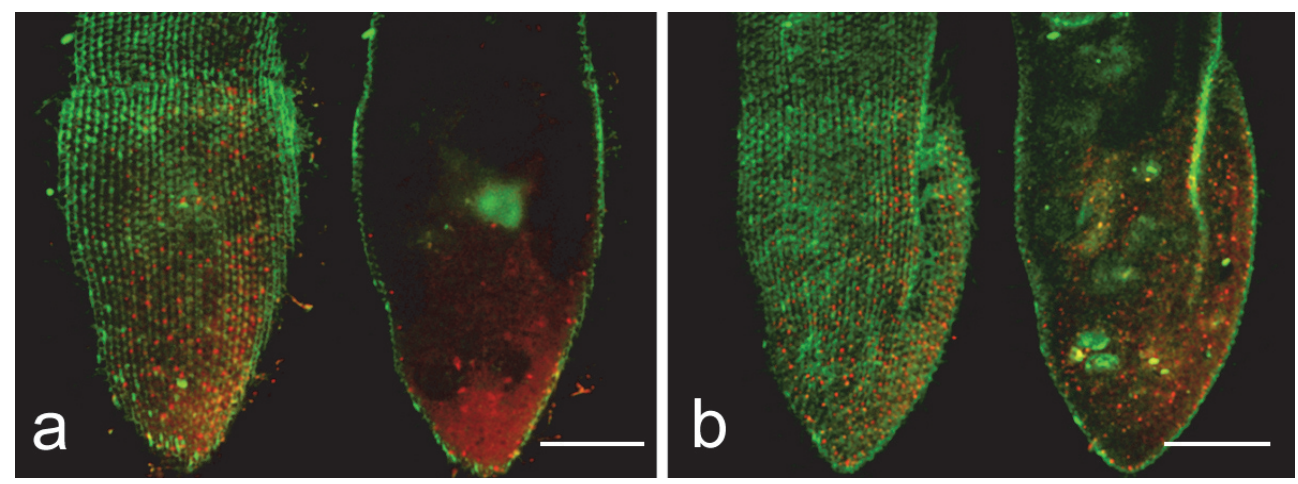

Figure 11. Fig. 11. Inhibition of clathrin-mediated endocytosis. (a) Effect of hypertonic medium on fluid phase and membrane mediated transport. Cells blocked in phagocytic activity are incubated in $0.20 \mathrm{M}$ sucrose, WGA-FITC and dextran-TXR for $10 \mathrm{~min}$. Sucrose inhibits WGA internalization and reduces dextran internalization. (b) Effect of cytosol acidification on fluid phase and membrane mediated transport. Cells blocked in phagocytic activity are incubated in $10 \mathrm{mM}$ acetic acid, $\mathrm{pH}$ 5.0, WGA-FITC and dextran-TXR for $5 \mathrm{~min}$. Green fluorescence is localized on the plasma membrane and red fluorescence in vesicles in both the cortical region and throughout the cytoplasm. $(a, b)$ Two images of the same cell acquired at different focus planes from the dorsal side (left) to the internal cytoplasm (right). Bars, $20 \mu \mathrm{m}$. 
Conversely, dextran internalization is blocked by filipin and nystatin (Figure 12), sterolbinding agents that disrupt caveolar structure and function [58].

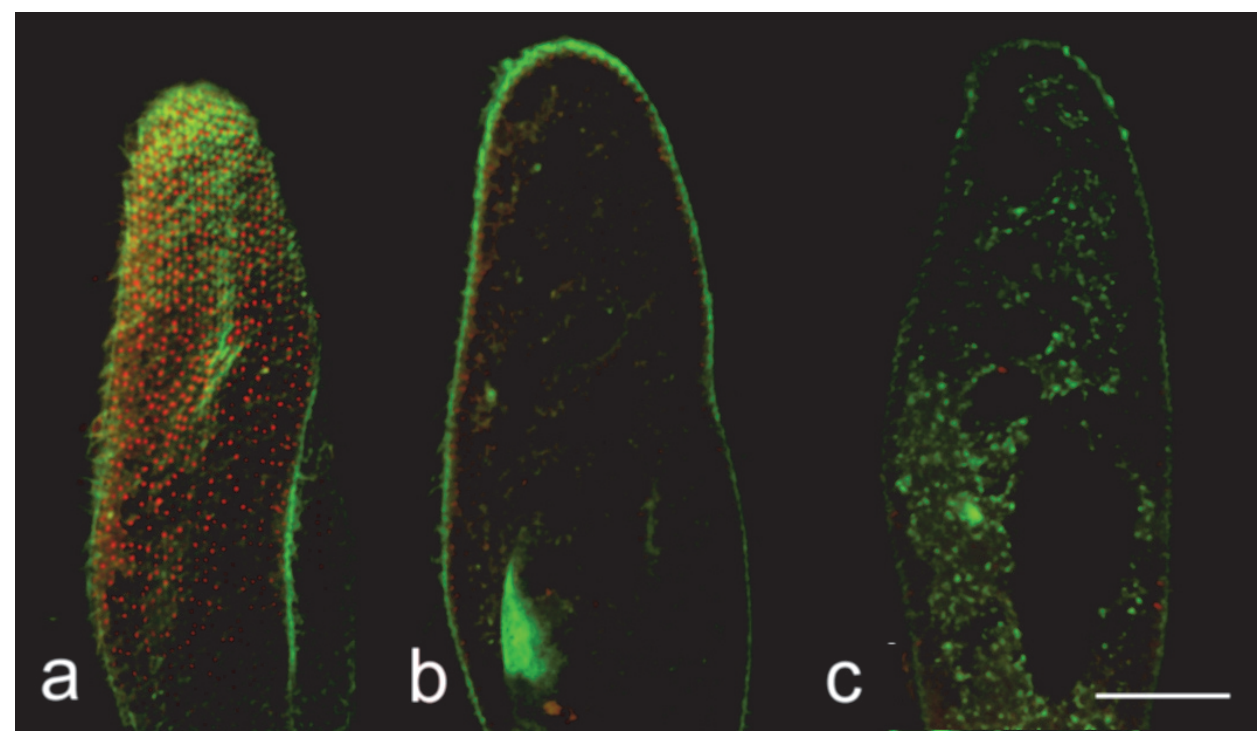

Figure 12. Inhibition of clathrin-independent endocytosis. Effect of nystatin on fluid phase and membrane mediated transport. Cells blocked in phagocytic activity are incubated in $2 \mu \mathrm{g} / \mathrm{ml}$ nystatin, WGA-FITC and dextran-TXR for $5(a, b)$ and $20 \mathrm{~min}$ (c) min. (a) and (b) are images of the same cell acquired at different focus planes. Green fluorescence locate on the plasma membrane and in vesicles through the cytoplasm; no red vesicles are seen inside the cell. Bar, $20 \mu \mathrm{m}$.

\section{Receptor internalization and recycling}

\subsection{Receptor endocytosis}

The classical paradigm of receptor function assumes that receptors localize on the cell surface and are activated by the binding of agonist ligands. After activation, most receptors are endocytosed from cell surface and travel to low $\mathrm{pH}$ endosomes, allowing the ligand to detach before the receptor is recycled back to the cell surface or sent through late endosomes to lysosomes for degradation [59]. Increasing evidence shows that some G protein-coupled receptors are not totally inactive in the absence of ligands but exhibit a constitutive activity, too, with elevated basal levels of intracellular signaling [60,61]. It was found that receptor internalization from the neuronal surface occurring both constitutively and in response to agonist exposure is mediated by clathrin-dependent endocytosis [62-64]. Clathrin-coated vesicles are the initial vehicles for sequestration of surface receptors, which are ultimately degraded or recycled. Endocytosis of such membrane proteins involves a series of steps beginning with the clustering of receptors at specific sites of the plasma membrane, regions that later turn into clathrin-coated pits. Receptors do this by recruiting cytosolic AP2 adaptor complexes through their cytoplasmic tails. 
AP2 is a key component of the endocytic machinery that links cargo membrane proteins to the clathrin lattice, selects molecules for sorting into clathrin-coated vesicles and recruits clathrin to the plasma membrane [65-69]. It is composed of subunits: $\alpha, \beta 2, \mu 2$, and $\sigma$. The $\mu 2$ subunit (AP50) binds the endocytic sequence motif of cargo proteins, whereas the $\beta 2$ subunit binds to clathrin and the $\alpha$ region interacts via distinct domains with amphiphysin, AP180 and eps15. In addition to the AP2 adaptor complex, amphiphysin interacts with dynamin and the disruption of dynamin-amphiphysin interaction by recombinant amphiphysin src homology 3 (SH3) domain in vivo leads to a potent block in clathrin-mediated endocytosis [70, 71]. Dynamin, a large GTP-binding protein, pinches off vesicles at constricted clathrin-coated pits by forming a ring-like structure collaring the neck of the vesicle that is thought to drive vesicle separation. Eps15 binds the C-terminal domain of the AP2 adaptor $\alpha$-subunit and mediates the interaction of AP2 with proteins such as epsin, CALM/AP180 and synaptojanin, implicated in regulation of receptor-mediated endocytosis. Eps15 function in clathrin-dependent endocytosis seems to be restricted to the early events leading to clathrin-coated pit formation: indeed eps15 is not present in clathrin-coated vesicles [72].

It has been shown that endocytosis of receptors may also occur through other membrane structures, including noncoated membrane invaginations [73, 74] and caveolae [75]. The $\beta_{2}-$ adrenergic receptor, which is endocytosed by clathrin-coated pits in several cell types [76, 77], is endocytosed by membrane invaginations resembling to caveolae in other cells [74, 75]. Cholecystokinin receptors have been observed in both clathrin-coated pits and caveolae in the same cells [73]. Caveolae are cholesterol- and sphingolipid-rich smooth invaginations of the plasma membrane that partition into raft fractions and the expression of which is associated with caveolin 1.

A clathrin- and dynamim-dependent mechanism in the $\beta_{2}$-adrenergic receptor internalization has been already shown in Paramecium [78, 79]. An homologue of dynamin, a protein present in mammalian cells with three isoforms generating more than 25 possible spliced variants expressed in a tissue-specific manner, was identified in Paramecium, too [80]. A gene fragment of this dynamin reveals $74 \%$ similarity to human dynamin 2 mRNA and the deduced amino acid sequence shows $61.1 \%$ homology in a 175 amino acid overlap to the $\mathrm{N}$-terminal region of human, mouse and rat dynamin [81]. Endocytosis in Tetrahymena also involves a protein in the dynamin family [82].

\subsection{Receptor trafficking after internalization}

Endocytosis of receptors can contribute to functional resensitization of signal transduction by promoting dephosphorylation and recycling of receptors to the plasma membrane [83] as well as to down-regulation of receptors, a process that leads to functional desensitization of signal transduction by reducing the number of receptors present in the plasma membrane and promoting degradation of receptors in lysosomes [73, 84, 85].

These processes of receptor regulation are thought to involve membrane trafficking of receptors via distinct recycling or degradative pathways and can mediate opposite effects on the regulation of functional signal transduction [83, 86]. Golgi-derived vesicles provide 
newly synthesized receptors to the cell surface, whereas clathrin coated vesicles are the initial vehicles for sequestration of surface receptors, which are ultimately degraded or recycled back to the plasma membrane, either directly or through the recycling endosomes [87-89]. These processes are mediated by a continuous traffic of vesicular and tubular intermediates which needs to be coordinated to ensure proper progression of cargo through the different compartments. Several rab family members have been localized to distinct compartments of the endocytic pathway and play different roles in endocytosis and recycling [90-93]. Rab5 and rab4 are both localized to early endosomes but exert opposite effects on the uptake of membrane-bound proteins. Rab5 plays a role in the formation of clathrin-coated vesicles at the plasma membrane [94], their subsequent fusion with early endosomes, in the homotypic fusion between early endosomes $[95,96]$ and in the interaction of early endosomes with microtubules [97]. Rab4 has been implicated in the regulation of membrane recycling from the early endosomes to the recycling endosomes or directly to the plasma membrane [98].

In accordance with this functional diversity, rab5 lies at the center of a complex machinery comprising several effector proteins [99]. Of these proteins, EEA1 was identified as a core component of the homotypic endosome docking and fusion machinery and was shown to play a role in the docking/tethering of the endosome membranes [99]. EEA1 is predominantly localized to the early endosomes and is regarded as a specific marker of this compartment. Because of this localization and given its function in endosome membrane docking [99] it has been proposed that EEA1 may confer directionality to rab5-dependent vesicular transport to the early endosomes. Another effector protein for rab5 is rabaptin-5. Rabaptin-5 binds directly to the GTP-bound form of rab5 and is recruited to early endosomes by rab5 in a GTP-dependent manner [100], stabilizes rab5 in the GTP-bound active form by down-regulating GTP hydrolysis [101] and, finally, it is required for the homotypic fusion between early endosomes as well as for the heterotypic fusion of clathrincoated vesicles with early endosomes in vitro [100, 102]. Rabadpin-5 also interacts, via a distinct structural unrelated N-terminal RBD, with GTP-bound rab4 but does not appear to interact with rab11, a GTPase that is highly enriched on the recycling endosome and whose activity is required for receptor recycling through this compartment [89]. Thus the same effector interacts with the two rab proteins which act sequentially in transport through the early endosomes. Furthermore, the lysosomal sorting of receptors is dependent upon rab 7 activity [103].

Small GTPase rab is a widely conserved molecular switch among eukaryotes and regulates membrane trafficking, also in ciliates. In the T. thermophila genome 56 different rab protein genes were identified [104]. These do not include 17 putative rabs previously reported [82]. This is a remarkable number, considering that somewhat over 63 rabs have been identified in humans [105]. Some of them are very conserved and some others are ciliate specific [104, 106]. Endocytic compartments were found to be associated with a large number of rabs, including both conserved endocytic rabs but also a roughly equal number of divergent rabs. One of the conserved rabs did not fall into any of the proposed core clades. The animal rabs in this clade are associated with transport of lysosome-related organelles, while the 
Tetrahymena protein localized to phagosomes. The remaining 14 conserved rabs in Tetrahymena fall within five of the proposed core pathways: ER-to Golgi, endocytosis/recycling, endocytosis, retrograde Golgi and late endocytosis [104, 106].

86 rab genes in the Tetrahymena genome and 229 rab genes in P. tetraurelia were found by Saito-Nakano et al. [107]. By comparing the amino acid sequence of rabs in humans and the budding yeast Saccharomyces cerevisiae, 42 conventional and 44 species-specific rabs were categorized in Tetrahymena and 157 conventional and 72 species-specific rabs in Paramecium. Among them, nine Paramecium rab genes showed high homology to seven Tetrahymena rabs, suggesting the conservation of ciliate-specific rab [107].

\subsection{Investigating the GАВАв receptor trafficking pathway in Paramecium using confocal microscopy}

In our studies we are interested in understanding the endocytic properties of GABAв receptors in Paramecium [108, 109]. Although most G protein-coupled receptors undergo endocytosis, the conditions and mechanisms of this process vary from receptor to receptor. Many of them are endocytosed via clathrin-coated pits, but some are not [110,111]. Some have an agonist-induced endocytosis, some are continuously endocytosed even in the absence of stimulation, while others exhibit both a constitutive and a stimulated endocytosis [110, 112, 113]. Currently, very little is known about the targeting and trafficking mechanisms of GABAв receptor in cells. In the past years, attention has mainly been focused on endocytosis of ionotropic GABA (GABAA) receptors. It has been shown that GABAA receptors are internalized by a clathrin-coated pit-mediated process in hippocampal neurons and in A293 cells [114] and in a clathrin independent manner in HEK-293 cells [115]. Using a dominant-negative dynamin construct K44A Herring et al. [116] showed that constitutive endocytosis of GABAA receptors in HEK-293 cells is dynamin-mediated, while Cinar and Barnes [115] found that it is dynamin-independent. It was also shown that both recombinant and neuronal GABAA receptors can constitutively recycle between the cell surface and an intracellular endosomal compartment [117]. In Paramecium a dynamin- and clathrindependent pathway has been already observed [78, 79].

Constitutive internalization and intracellular trafficking of receptors in $P$. primaurelia was visualized by multiple immunofluorescence analysis using GABAв receptors as marker. GABАв receptors display a dotted vesicular pattern dispersed on the cell surface and throughout the cytoplasm (Figure 13a), and are internalized via clathrin-dependent and independent endocytosis. Indeed, GABAв receptors colocalize with the adaptin complex AP2, which is implicated in the selective recruitment of integral membrane proteins to clathrin-coated vesicles, and with caveolin 1, which is associated with uncoated membrane invaginations [109].

Cells were double labeled with a guinea pig anti-GАВАв receptor R1 subunit antibody and with a monoclonal anti-clathrin or anti-caveolin 1 antibody and visualized with Alexa Fluor 594-conjugated anti-guinea pig and Alexa Fluor 488-conjugated anti-mouse secondary 
antibodies, respectively. Staining with anti-clathrin or antI-caveolin antibody led to a punctuate pattern throughout the cytoplasm representing endocytic vesicles. The expression of GАВАв receptors and clathrin- or caveolin-coated vesicles exhibited a clustered distribution on the cell membrane and inside the cytoplasm (Figure13). Importantly, GABAв receptor and clathrin- or caveolin-coated vesicle clusters were partly colocalized (yellow fluorescence). Furthermore, GABAв receptors colocalize with $\beta_{2}$ adaptin in a number of sites on the plasma membrane [109].
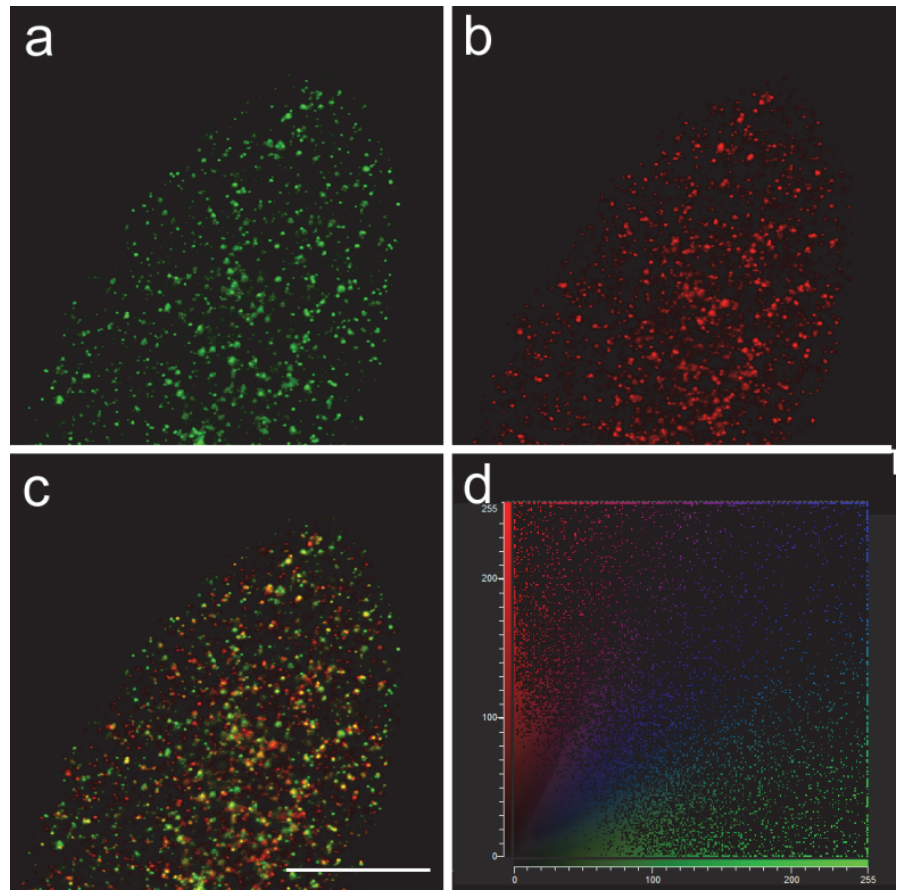

Figure 13. Colocalization of GABAв receptors and clathrin. In cells labeled with a polyclonal antibody against GABAв receptor (b) and a monoclonal antibody against clathrin HC (a), a clustered distribution of fluorescence is detected on the plasma membrane and inside the cytoplasm. GABAв receptors and clathrin vesicles are partly colocalized (c, yellow fluorescence). Bar, $20 \mu \mathrm{m}$. (d) 2D cytofluorogram: colocalized pixels are clustered along the diagonal line (visualized in blue).

In addition, we have shown that GABAв receptors are removed from the plasma membrane by clathrin-dependent and -independent endocytosis by blocking receptors internalization by hypertonic sucrose. However, it has recently been found that sucrose inhibits GABAA receptor endocytosis that is not mediated by clathrin-coated pits [115]. Therefore, we have also used cytosol acidification with acetic acid for clathrin-mediated endocytosis inhibition [50]. Furthermore, GABАв receptor internalization in Paramecium is blocked by filipin and nystatin, cholesterol binding drugs. The sensitivity of endocytosis to nonacute cholesterol depletion with agents such as filipin and nystatin distinguishes caveolae and raft pathways from clathrin-dependent and constitutive pinocytosis pathways [118]. 
Treatment of cells with $150 \mathrm{mM}$ sucrose or cytosol acidification significantly inhibited the internalization of receptors, as shown by the considerable reduction in receptors inside the cytoplasm (Figure 14) as compared to the control (Figure14b). This observation strongly suggests that $\mathrm{GABA}_{\mathrm{B}}$ receptor internalization in Paramecium is mediated by clathrindependent endocytosis. In these experiments phagocytosis was blocked by trifluoperazine.

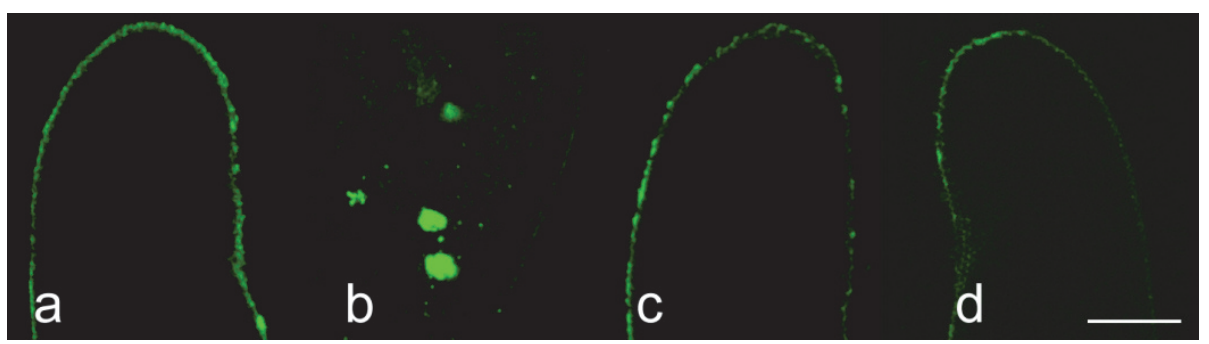

Figure 14. GАВАв-receptor internalization is mediated by clathrin-coated vesicles. In cells whose phagocytic activity is blocked by trifluoperazine, 20-minute treatment with $150 \mathrm{mM}$ sucrose (c) or citosol acidification (d) inhibits receptor internalization, which can be seen by receptor accumulation on the cell membrane and receptor reduction inside the cytoplasm. Controls are cells incubated with the anti-GABАв receptor antibody for 1 (a) and $20 \mathrm{~min} \mathrm{(b)} \mathrm{in} \mathrm{the} \mathrm{absence} \mathrm{of} \mathrm{inhibitors;} \mathrm{the} \mathrm{antibody} \mathrm{is}$ localized in endosomes and phagosomes. Incubation temperature, $25^{\circ} \mathrm{C}$. Bar, $20 \mu \mathrm{m}$.

Moreover, when endocytosis was blocked by filipin or by nystatin the receptor internalization decreased (Figure 15). In these experiments cells were incubated in the anti-GABAв receptor antibody for 30 minutes at $4^{\circ} \mathrm{C}$ (temperature inhibiting phagosome and endosome formation, [16], so that receptors were accumulated on the cell membrane (Figure 15a). After removal of the excess of antibody, cells were incubated at $25^{\circ} \mathrm{C} .84 \%$ receptors were internalized in untreated cells after 20 minutes incubation at $25^{\circ} \mathrm{C}$, as shown both by the reduction of cell membrane fluorescence intensity and by the fluorescence localization into endosomes and phagosomes (Figure 15b). Only $37 \%$ and $46 \%$ fluorescence was internalized in filipin $(\mathrm{p}<0.01)$ and nystatin-treated cells $(\mathrm{p}<0.01)$, respectively (Figure 16).

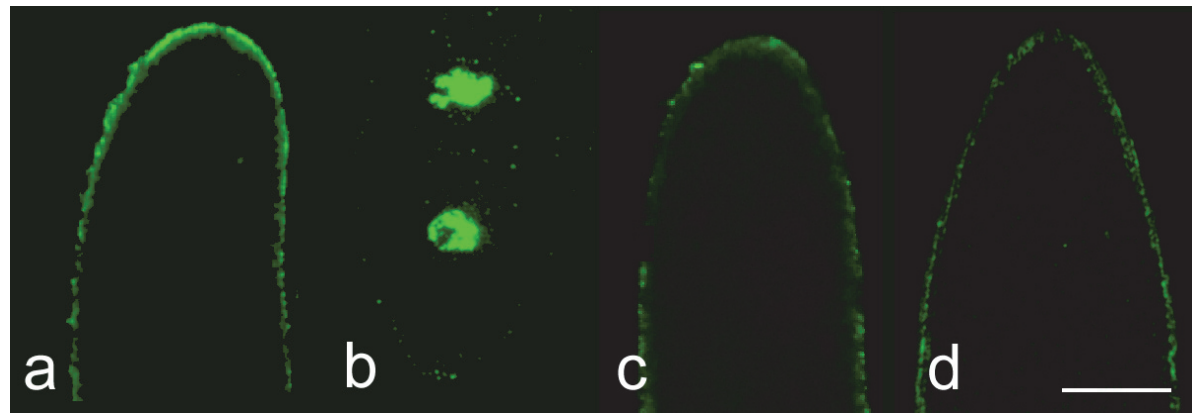

Figure 15. GАВАв receptors are internalized by non-coated endocytosis. Cells preincubated at $4^{\circ} \mathrm{C}$ for 30 minutes and labeled with anti-GABАв receptor antibody for 30 minutes (a) are fixed after a 20minute chase at $25^{\circ} \mathrm{C}$ in the absence (b) or in the presence of non-coated-pit endocytosis inhibitors filipin (c) and nystatin (d). Bar, $20 \mu \mathrm{m}$. 


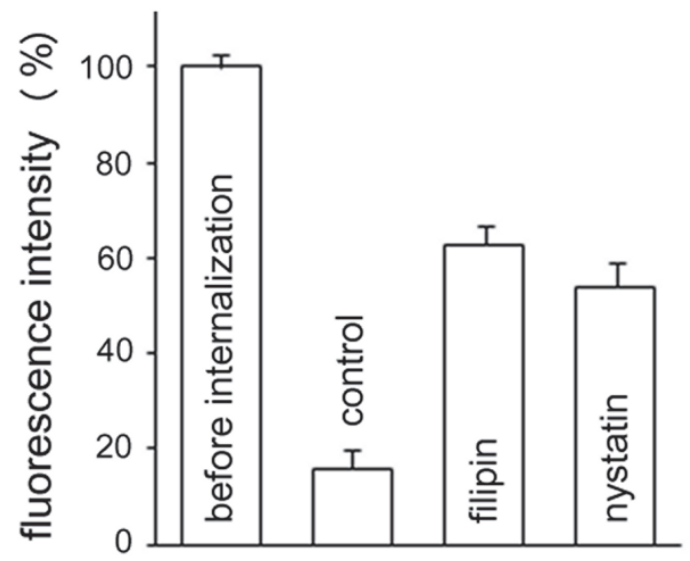

Figure 16. Measurement of the internalization shown in Figure 15. Constitutive receptor internalization is partially inhibited by filipin and nystatin ( $38 \%$ and $47 \%$, respectively); $P<0.01$, Student's $t$-test). Data were normalized to cells before internalization at $25^{\circ} \mathrm{C}$ (shown in Figure15a).

Colocalization values reported in Table 1 and experiments carried out in living cells suggest that $\mathrm{GABAв} \mathrm{receptors} \mathrm{are} \mathrm{internalized} \mathrm{through} \mathrm{the} \mathrm{two} \mathrm{pathways} \mathrm{in} \mathrm{a} \mathrm{similar} \mathrm{quantity.}$ Quantification of cell membrane fluorescence was performed by ImageJ $1.46 \mathrm{~b}$ software (Wayne Rasband, Nat. Inst. of Health, USA).

\begin{tabular}{lccc}
\hline Red & Green & Red/green (\%) & Green/red (\%) \\
\hline GABAв receptor & Clathrin & $18 \pm 3$ & $19 \pm 3$ \\
GABAв receptor & Caveolin 1 & $21 \pm 6$ & $25 \pm 4$ \\
\hline
\end{tabular}

Every colocalization value is the average from four optical sections of ten cells. Data were calculated as the mean \pm s.e. and are given in percent.

Table 1. Colocalization of GABAв receptor labeling with proteins involved in endocytosis

After internalization by clathrin-coated vesicles and by caveolae GABAв receptors are transported by rab5-linked vesicles to early endosomes, characterized by the EEA1 marker. Receptors are then partly recycled back to cell membrane and partly degraded. The recycling of GАВАв receptors is evidenced by the overlapping of their immunolocalization with both rab4 and rab11 immunostaining. Rab4 controls the rapid recycling of cargo proteins directly back to the cell surface from rab4/rab5 positive endosomal structures, and the slow recycling of cargo via rab11 positive recycling endosomes. The traffic of GABAв receptors to Golgi apparatus is evidenced by colocalization of GABAв with TGN38 immunoreactivity. The communication between contiguous rab-domains and thereby the sequential transport of receptors from one intracellular compartment to another is regulated by rab effector rabaptin-5. Furthermore a fraction of GABAв R1 seemed to be directed to lysosomes, as shown by GABAв R1 and LAMP1 (lysosomal marker) immunocolocalization, and to phagosomes for degradation. An immunolocalization of rab7 on phagosomal membrane was also reported in Paramecium [119-122]. 
Colocalization of GАВАв receptors with proteins involved in the endocytosis and recycling was demonstrated by both the colocalized pixels in a 2D cytofluorogram and the similarity of green and red profiles along the $z$-axes of fluorescence intensity of double-stained vesicles [109]. 2D cytofluorogram (Figure 14d) was generated using ICA plugin of ImageJ. Colocalization along the $z$-axes of double-stained vesicles is also demonstrated by the similarity of green and red profiles of their fluorescence intensity of double-labeled vesicles from a stack of 30 images (total thickness $2 \mu \mathrm{m}$ ). For three different focal planes a sample of a vesicle that shows colocalization (yellow fluorescence) was selected (Figure 17).
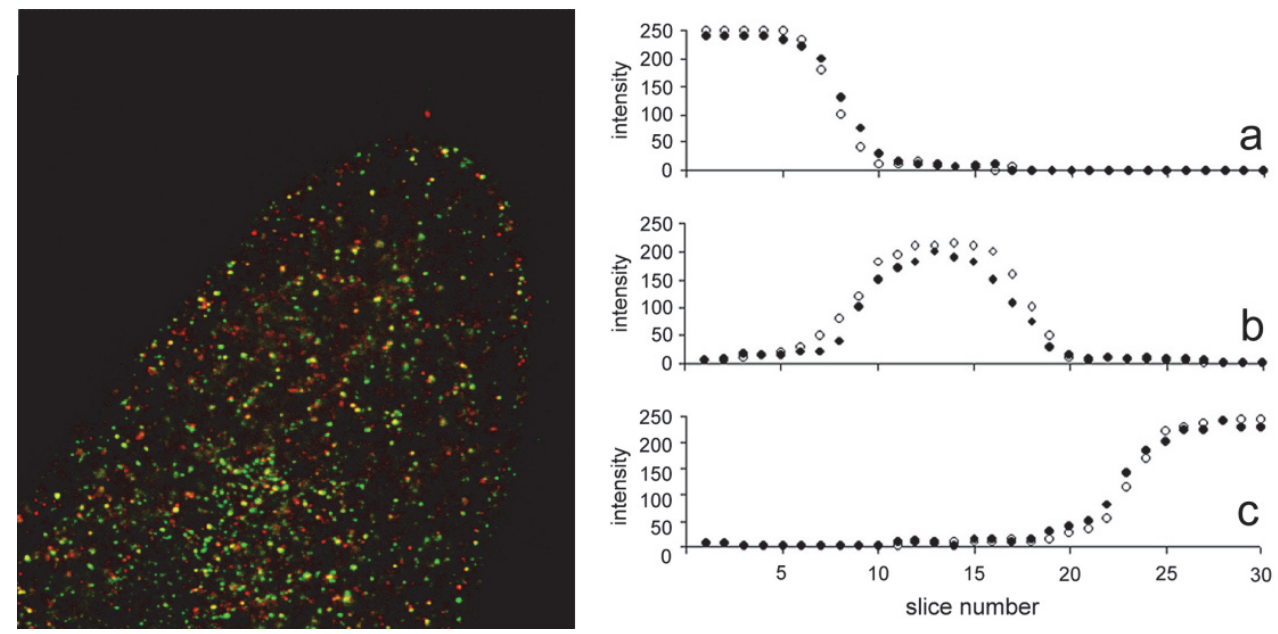

Figure 17. $z$-Stack profile of fluorescence intensity of double-labeled vesicles. The left side of the figure shows a optical plane from a stack of 30 images (total thickness $2 \mu \mathrm{m}$ ). The right side of the figure shows fluorescence-intensity distribution along the $z$-axis of three yellow-labeled vesicles selected from different optical planes ( $a$, top; b, middle; c, bottom) (green, open circle; red, filled circle).

The quantitative estimation of colocalized proteins in immunocytochemical studies has been performed calculating the colocalization coefficients [123] from the red- and green-channel scatterplot. Colocalization coefficients express the fraction of colocalizing molecular species in each component of a dual-color image and are based on the Pearson's correlation coefficient, a standard procedure for matching one image with another in pattern recognition [124]. If two molecular species are colocalized, the overlay of their spatial distributions has a correlation value higher than what would be expected by chance alone. Costes et al. [125] developed an automated procedure to evaluate correlation between the green and red channels with a significance level $>95 \%$. The same procedure automatically determines an intensity threshold for each color channel based on a linear least-square fit of the green and red intensities in the image's 2D correlation cytofluorogram. Costes' approach has been accomplished by macro routines integrated as plug-ins (WCIF Co-localization Plugins, Wright Cell Imaging Facility, Toronto Western Research Institute, Canada) in the ImageJ 1.46b image-analysis software (Wayne Rasband, NIH, USA). 


\section{Conclusion}

In ciliates, essential components of membrane trafficking during endocytosis have been identified, based on work mainly with Paramecium and Tetrahymena. We used P. primaurelia and laser scanning microscopy to show in vivo vesicle formation, movement and fusion. The retrieval of membrane of stage III and stage IV food vacuoles, and recycling back both to nascent food vacuoles as small vesicles and to the acidified food vacuoles (stage II) as secondary lysosomes have been clearly and dynamically documented. Furthermore, the multimodal analysis using the pseudo-color technique enabled us to observe the changes in the direction of movement of pinocytic vesicles after evagination from food vacuoles.

Using endocytosis markers and confocal microscopy we have also shown that WGA and dextran enter the cell via two distinct vesicle populations and that in Paramecium, as in mammalian cells, fluid phase endocytosis is unaffected by treatments that arrest coated pitmediated endocytosis, indicating that fluid phase endocytosis is primarily clathrinindependent. So, plasma membrane components are internalized by endosomes, which are first localized in the cortical region of the cell, transported in the most internal cytoplasmic portion and fused with other endosomal compartments, until their content is transferred to the phagosomes.

Furthermore, GАВАв receptors are removed from the plasma membrane by clathrindependent and -independent endocytosis. Indeed, internalization of receptors is blocked by hypertonic sucrose and cytosol acidification, classic inhibitors of clathrin-mediated endocytosis, as well as by nystatin and filipin, sterol-binding agents that disrupt caveolar structure and function.

Using standard immunomarkers for early endosomes, recycling vesicles and lysosomes, and comparing our data with those obtained in mammalian cells relating to the internalization and recycling of some other receptors, we inferred that also in Paramecium GABAв receptors are partly recycled to cell plasma membrane and partly degraded into lysosomes. So, using immunohistochemical methods we demonstrated that in the single-celled organism Paramecium, as in mammalian cells, rab-like proteins are involved in the vesicle transport from one compartment to another.

\section{Author details}

Paola Ramoino*

Department of Earth, Environment and Life Sciences (DISTAV),

University of Genoa, Genova, Italy

Alberto Diaspro

The Italian Institute of Technology (IIT), Nanophysics Unit, Genova, Italy

${ }^{*}$ Corresponding Author 
Marco Fato

Department of Communication, Computer and System Sciences (DIST),

University of Genoa, Genova, Italy

Cesare Usai

Institute of Biophysics, CNR Genoa, Genova, Italy

\section{References}

[1] Hall RP (1965) Protozoan Nutrition. Blaisdell Publishing Company, New York.

[2] Nisbet B (1984) Nutrition and Feeding Strategies in Protozoa. Croom Helm, London.

[3] Radek R, Hausmann K (1996) Phagotrophy of ciliates. In: Hausmann K, Bradbury PC, editors. Ciliates: Cells as Organisms. Gustav Fischer Verlag, Stuttgart, pp. 197-219.

[4] Verni F, Gualtieri P (1997) Feeding behaviour in ciliated protists. Micron 28: 487-504.

[5] Hausmann K (2002) Food acquisition, food ingestion and food digestion by protists. Jpn. J. Protozool. 35: 85-95.

[6] Mast SO (1947) The food-vacuole in Paramecium. Biol. Bull. 92: 31-72.

[7] Fenchel T (1980) Suspension feeding in ciliated protozoa: structure and function of feeding organelles. Arch. Protistenkd. 123: 239-260.

[8] Giese AC (1973) Cannibalism and gigantism in Blepharisma. Trans. Amer. Micros. Soc. 57: 245-255.

[9] Allen RD (1974) Food vacuole membrane growth with microtubule-associated membrane transport in Paramecium. J. Cell Biol. 63: 904-922.

[10] Allen RD, Wolf RW (1974) The cytoproct of Paramecium caudatum: structure and function, microtubules, and fate of food vacuole membranes. J. Cell Sci. 14: 611-631.

[11] Müller M., Törö I (1962) Studies on feeding and digestion in protozoa. III. Acid phosphatase activity in food vacuoles of Paramecium multimicronucleatum. J. Protozool. 9: 98-102.

[12] Müller M, Röhlich P, Toth J, Törö I (1963) Fine structure and enzymic activity of protozoan food vacuoles. Ciba Found. Symp. Lysosomes, Churchill, London, pp. 201216.

[13] Allen RD, Staehelin LA (1981) Digestive system membranes: freeze-fracture evidence for differentiation and flow in Paramecium. J. Cell Biol. 89: 9-20.

[14] Fok AK, Lee Y, Allen RD (1982) The correlation of digestive vacuole $\mathrm{pH}$ and size with the digestive cycle in Paramecium caudatum. J. Protozool. 29: 409-414.

[15] Allen RD, Fok AK (1984) Retrieval of lysosomal membrane and acid phosphatase from phagolysosomes of Paramecium caudatum. J. Cell Biol. 99: 1955-1959.

[16] Fok AK, Muraoka JH, Allen RD (1984) Acid phosphatase in the digestive vacuoles and lysosomes of Paramecium caudatum: a timed study. J. Protozool. 31: 216-220.

[17] Allen RD, Fok AK (2000) Membrane trafficking and processing in Paramecium. Int. Rev. Cytol. 198: 277-318.

[18] Kuznicki L, Sikora J (1971) Cytoplasmic streaming within Paramecium aurelia. I. Movements of crystals after immobilization by antiserum. Acta Protozool. 8: 439-445. 
[19] Ramoino P, Beltrame F, Diaspro A, Fato M (1996) Time-variant analysis of organelle and vesicle movement during phagocytosis in Paramecium primaurelia by means of fluorescence confocal laser scanning microscopy. Microsc. Res. Tech. 35: 377-384.

[20] Kuznicki L (1963) Reversible immobilization of Paramecium caudatum evoked by nickel ions. Acta Protozool. 1: 301-312.

[21] Brutkowska M (1967) Immobilization effect of $\mathrm{NiC1}_{2}$ and food vacuole formation in Paramecium caudatum. Boll. Acad. Pol. Sci. Cl II, 15: 119-122.

[22] Sikora J, Wasik A (1978) Cytoplasmic streaming with $\mathrm{Ni}^{2+}$ immobilized Paramecium aurelia. Acta Protozool. 17: 389-397.

[23] Robbins E, Marcus P, Gonotas NK (1964) Dynamics of acridine orange-cell interaction. II. Dye-induced ultrastructural changes in multivesicular bodies (acridine orange particles). J. Cell Biol. 21: 49-62.

[24] Zelenin AV (1966) Fluorescence microscopy of lysosomes and related structures in living cells. Nature 212: 425-426.

[25] Allen RD, Fok AK.(1983) Nonlysosomal vesicles (acidosomes) are involved in phagosome acidification in Paramecium. J. Cell Biol. 97: 566-570.

[26] Beltrame F, Diaspro A, Fato M, Martin I, Ramoino P, Sobel I (1995) Use of stereo vision and 24-bit false colour imagering to enhance visualisation of multimodal confocal images. Proc. SPIE 2412: 222-229.

[27] Aufderheide KJ (1977) Saltatory motility of uninserted trichocysts and mitochondria in Paramecium tetraurelia. Science 198: 299-300.

[28] Sikora J (1981) Cytoplasmic streaming in Paramecium. Protoplasma 109: 57-77.

[29] Schroeder CC, Fok AK, Allen AD (1990) Vesicle transport along microtubular ribbons and isolation of cytoplasmic dynein from Paramecium. J. Cell Biol. 111: 2553-2562.

[30] Ramoino P (1996/97) Membrane supply and food vacuole formation in Paramecium primaurelia. Arch. Protistenkd. 147: 323-329.

[31] Mellman I, Howe C, Helenius A (1987) The control of membrane traffic on the endocytic pathway. Curr .Top. Membr. Transp. 29: 255-288.

[32] Courtoy PJ (1989) Dissection of endosomes. In: Steer C, Hanover J editors Intracellular Trafficking of Proteins, Cambridge University Press, New York, pp 103-156.

[33] Gruenberg J, Howell KE (1989) Membrane traffic in endocytosis: insights from cell-free assay. Annu. Rev. Cell Biol. 5: 453-481.

[34] van Deurs B, Petersen OW, Olsnes S, Sandvig K (1989) The ways of endocytosis. Int. Rev. Cytol. 171: 131-176.

[35] Chapman-Andresen C (1962) Studies on pinocytosis in Amoebae. Comp. Rend. Trav. Lab. Carlsberg 33: 73-264.

[36] Stockem W, Christofidou-Solomidou M (1993) Food uptake and digestion in amoebae. In: H. Plattner, editor. Membrane Traffic in Protozoa. JAI Press Inc., Greenwich (Conn.), USA, pp. 371-407.

[37] Stockem W (1977) Endocytosis. In: Jamieson GA, Robinson DM, editors. Mammalian Cell Membranes, vol. 5. Butterworths, London, pp 151-195.

[38] Munch R. (1970): Food uptake by endocytosis in Opalina ranarum. Cytobiologie 2: 108122. 
[39] Allen RD (1988) Cytology. In: Görtz H-D, editor. Paramecium, Springer-Verlag, Berlin Heidelberg, pp 4-40.

[40] Nilsson JR, van Deurs P (1983) Coated pits and pinocytosis in Tetrahymena. J. Cell Sci. 63: 209-222.

[41] Allen RD, Schroeder CC, Fok AK (1992) Endosomal system of Paramecium: coated pits to early endosomes. J. Cell Sci. 101: 449-461.

[42] Allen RD, Fok AK (1993) Endosomal membrane traffic of ciliates. In: Plattner H, editor. Advances in Cell and Molecular Biology of Membranes, Membrane Traffic in Protozoa, JAI Press Inc, Greenwich, CT, pp 283-309.

[43] Lamaze C, Schmid SL (1995) The emergence of clathrin-independent pinocytic pathways. Curr. Opin. Cell Biol. 7: 573-580.

[44] Wyroba E (1991) Quantitation of fluid phase uptake in Paramecium. 1. Kinetics in the cells blocked in phagocytic activity. Cell Biol. Int. Rep. 15: 1207-1216.

[45] Wyroba E (1987) Stimulation of Paramecium phagocytosis by phorbol ester and forskolin. Cell Biol. Int. Rep. 11: 657-664.

[46] Allen RD, Ueno MS, Fok AK (1988) A survey of lectin binding in Paramecium. J. Protozool. 35: 400-407.

[47] Ramoino P (1997) Lectin-binding glycoconjugates in Paramecium primaurelia: changes with cellular age and starvation. Histochem. Cell Biol. 107: 321-329.

[48] Ramoino P, Fronte P, Diaspro A, Fato M, Beltrame F, Robello M (2001) Fluid phase and receptor mediated endocytosis in Paramecium. Europ. Biophys. J. Biophys. 30: 305-312.

[49] Daukas G, Zigmond SH (1985) Inhibition of receptor-mediated but not fluid-phase endocytosis in polymorphonuclear leukocytes. J. Cell Biol. 101: 1673-1679.

[50] Davoust J, Gruenberg J, Howell K E (1987) Two threshold values of low pH block endocytosis at different stages. EMBO J. 6: 3601-3609.

[51] Sandvig K, Olsnes S, Petersen OW, van Deurs B (1987) Acidification of the cytosol inhibits endocytosis from coated pits. J. Cell Biol. 105: 679-689.

[52] Hansen SH, Sandvig K, van Deurs B (1993) Molecules internalized by clathrinindependent endocytosis are delivered to endosomes containing transferrin receptors. J. Cell Biol. 123: 89-97.

[53] Hansen SH, Sandvig K, van Deurs B (1993) Clathrin and HA2 adaptors: effects of potassium depletion, hypertonic medium, and cytosol acidification. J. Cell Biol. 121: 6172.

[54] Heuser J (1989) Effects of cytoplasmic acidification on clathrin lattice morphology. J. Cell Biol. 108: 401-411.

[55] Heuser JE, Anderson RG (1989) Hypertonic media inhibit receptor-mediated endocytosis by blocking clathrin-coated pit formation. J. Cell Biol. 108: 389-400.

[56] Wang L-H, Rothberg KG, Anderson RGW (1993) Mis-assembly of clathrin lattices on endosomes reveals regulatory switch for coated pit formation. J. Cell Biol. 123: 11071117.

[57] Sofer A, Futherman AH (1995) Cationic amphiphilic drugs inhibit the internalization of colera toxin to the Golgi apparatus and the subsequent elevation of cyclic AMP. J. Biol. Chem. 270: 12117-12122. 
[58] Schnitzer JE, Oh P, Pinney E, Allard J (1994) Filipin-sensitive caveolae-mediated transport in endotelium: reduced transcytosis, scavenger endocytosis, and capillary permeability of selected macromolecules. J. Cell Biol. 127: 1217-1232.

[59] Ferguson SS (2001) Evolving concepts in G protein-coupled receptor endocytosis: the role in receptor desensitization and signaling. Pharmacol. Rev. 53: 1-24.

[60] Seifert R, Wenzel-Seifert K (2002) Constitutive activity of G-protein-coupled receptors: cause of disease and common property of wild-type receptors. Naunyn. Schmiedebergs Arch. Pharmacol. 366: 381-416.

[61] Royle SJ, Murrell-Lagnado RD (2003) Constitutive cycling: a general mechanism to regulate cell surface proteins. BioEssays 25: 39-46.

[62] Tehrani MHJ, Barnes EM, Jr (1997) Sequestration of gamma-aminobutyric acid A receptors on clathrin-coated vesicles during chronic benzodiazepine administration in vivo. J. Pharmacol. Exp. Ther. 283: 384-390.

[63] Grampp T, Notz V, Broll I, Fischer N, Benke D (2008) Constitutive, agonist-accelerated, recycling and lysosomal degradation of GABAв receptors in cortical neurons. Mol. Cell Neurosci. 39: 628-637.

[64] Traub LM (2010) Tickets to ride: selecting cargo for clathrin-regulated internalization. Nat. Rev. Mol. Cell Biol. 10: 583-596.

[65] Kirchhausen T (1999) Adaptors for clathrin-mediated traffic. Annu. Rev. Cell. Dev. Biol. 15: 705-732.

[66] Takei K, Haucke V (2001) Clathrin-mediated endocytosis: membrane factors pull the trigger. Trends Cell Biol. 11: 385-391.

[67] Traub LM (2003) Sorting it out: AP-2 and alternate clathrin adaptors in endocytic cargo selection. J. Cell Biol. 163: 203-208.

[68] Owen DJ, Collins BM, Evans PR (2004) Adaptors for clathrin coats: structure and function. Annu. Rev. Cell. Dev. Biol. 20: 153-191.

[69] Rodemer C, Haucke V (2008) Clathrin/AP-2-dependent endocytosis: a novel playground for the pharmacological toolbox? Handb. Exp. Pharmacol. 186: 105-122.

[70] Shupliakov O, Low P, Grabs D, Gad H, Chen H, David C, Takei K, De Camilli P, Brodin L (1997) Synaptic vesicle endocytosis impaired by distruption of dynamin-SH3 domain interactions. Science 276: 259-263.

[71] Wigge P, Kohler K, Vallis Y, Doyle CA, Owen D, Hunt SP, McMahon HT (1997) Amphiphysin heterodimers: potential role in clathrin-mediated endocytosis. Mol. Biol. Cell. 8: 2003-2015.

[72] Cupers P, Jadhav AP, Kirchhausen T (1998) Assembly of clathrin coats disrupts the association between Eps15 and AP-2 adaptors. J. Biol. Chem. 273: 1847-1850.

[73] Roettger BF, Rentsch RU, Pinon D, Holicky E, Hadac E, Larkin JM, Miller IJ (1995) Dual pathways of internalization of the cholecystokinin receptor. J. Cell Biol. 128: 1029-1041.

[74] Raposo, G., Dunia, I., Delavier-Klutchko, C., Kaveri, S., Strosberg, A. D. and Benetti, E.L. (1989) Internalization of beta-adrenergic receptor in A431 cells involves non-coated vesicles. Eur. J. Cell Biol. 50: 340-352.

[75] Dupree P, Parton RG, Raposo G, Kurzchalia TV, Simons K (1993) Caveolae and sorting in the trans-Golgi network of epithelial cells. EMBO J. 12: 1597-1605. 
[76] von Zastrow M, Kobilka BK (1994) Antagonist-dependent and -independent steps in the mechanism of adrenergic receptor internalization. Biol. Chem. 269: 18448-18452.

[77] Zhang J, Ferguson SS, Barak LS, Menard L, Caron MG (1996) Dynamin and betaarrestin reveal distinct mechanisms for $\mathrm{G}$ protein-coupled receptor internalization. J. Biol. Chem. 271: 18302-18305.

[78] Wiejak J, Surmacz L, Wyroba E (2004) Dynamin- and clathrin-dependent endocytic pathway in unicellular eukaryote Paramecium. Biochem. Cell Biol. 82: 547-558.

[79] Wiejak J, Surmacz L, Wyroba E (2004) Dynamin-association with agonist-mediated sequestration of beta-adrenergic receptor in single-cell eukaryote Paramecium. J. Exp. Biol. 207: 1625-1632.

[80] Wiejak J, Wyroba E (2002) Dynamin: characteristics, mechanisms of action and function. Cell Biol. Int. Rep. 13: 667-678.

[81] Surmacz L, Wiejak J, Wyroba E (2001) Alterations in the protein pattern of subcellular fractions isolated from Paramecium cells suppressed in phagocytosis. Folia Histochem. Cytobiol. 39: 301-305.

[82] Elde NC, Morgan G, Winey M, Sperling L, Turkewitz AP (2005) Elucidation of clathrinmediated endocytosis in Tetrahymena reveals an evolutionarily convergent recruitment of dynamin. PLoS Genet. 1: 52.

[83] Ferguson SS, Zhang J, Barak LS, Caron MG (1998) Molecular mechanisms of G proteincoupled receptor desensitization and resensitization. Life Sci. 62: 1561-1565.

[84] Hoxie JA, Ahuja M, Belmonte E, Pizarro S, Parton R, Brass LF (1993) Internalization and recycling of activated thrombin receptors. J. Biol. Chem. 268: 13756-13763.

[85] Kallal L, Gagnon AW, Penn RB, Benovic JL (1998) Visualization of agonist-induced sequestration and down-regulation of a green fluorescent protein-tagged beta2adrenergic receptor. J. Biol. Chem. 273: 322-328.

[86] Bohm SK, Khitin LM, Grady EF, Aponte G, Payan DG, Bunnett NW (1996) Mechanisms of desensitization and resensitization of proteinase-activated receptor-2. J. Biol. Chem. 271: 22003-22016.

[87] Yamashiro DJ, Maxfield FR (1984) Acidification of endocytic compartments and the intracellular pathways of ligands and receptors. J. Cell Biochem. 26: 231-246.

[88] Hopkins CR, Gibson A, Shipman M, Strickland DK, Trowbridge IS (1994) In migrating fibroblasts, recycling receptors are concentrated in narrow tubules in the pericentriolar area, and then routed to the plasma membrane of the leading lamella. J. Cell Biol. 125: 1265-1274.

[89] Ullrich O, Reinsch S, Urbe S, Zerial M, Parton RG. 1996. Rab11 regulates recycling through the pericentriolar recycling endosome. J. Cell Biol. 135: 913-924.

[90] Chavrier P, Parton RG, Hauri HP, Simons K, Zerial M (1990) Localization of low molecular weight GTP binding proteins to exocytic and endocytic compartments. Cell 62: 317-329.

[91] Van Der Sluijs P, Hull M, Zahraoui A, Tavitian A, Goud B, Mellman I (1991) The small GTP-binding protein rab4 is associated with early endosomes. Proc. Natl. Acad. Sci. USA 88: 6313-6317. 
[92] Olkkonen VM, Dupree P, Killisch I, Lutcke A, Zerial M, Simons K (1993) Molecular cloning and subcellular localization of three GTP-binding proteins of the rab subfamily. J. Cell Sci. 106: 1249-1261.

[93] Stenmark H (2009) Rab GTPases as coordinators of vesicle traffic. Nat. Rev. Mol. Cell Biol. 10: 513-525.

[94] McLauchlan H, Newell J, Morrice N, Osborne A, West M, Smythe E (1998) A novel role for Rab5-GDI in ligand sequestration into clathrin-coated pits. Curr. Biol. 8: 34-45.

[95] Gorvel JP, Chavrier P, Zerial M, Gruenberg J (1991) Rab5 controls early endosome fusion in vitro. Cell 64: 915-925.

[96] Bucci C, Parton RG, Mather IH, Stunnenberg H, Simons K, Hoflack B, Zerial M (1992) The small GTPase rab5 functions as a regulatory factor in the early endocytic pathway. Cell 70: 715-728.

[97] Nielsen E, Severin F, Backer JM, Hyman AA, Zerial M (1999) Rab5 regulates motility of early endosomes on microtubules. Nat. Cell Biol. 1: 376-382.

[98] Daro E, van der Sluijs P, Galli T, Mellman I (1996) Rab4 and cellubrevin define different early endosome populations on the pathway of transferrin receptor recycling. Proc. Natl. Acad. Sci. USA 93: 9559-9564.

[99] Christoforidis S, McBride HM, Burgoyne RD, Zerial M (1999) The Rab5 effector EEA1 is a core component of endosome docking. Nature 397: 621-625.

[100] Stenmark H, Vitale G, Ullrich O, Zerial M (1995) Rabaptin-5 is a direct effector of the small GTPase Rab5 in endocytic membrane fusion. Cell 83: 423-432.

[101] Rybin V, Ullrich O, Rubino M, Alexandrov K, Simon I, Seabra MC, Goody R, Zerial M (1996) GTPase activity of Rab5 acts as a timer for endocytic membrane fusion. Nature 383: 266-269.

[102] Horiuchi H, Lippe R, McBride HM, Rubino M, Woodman P, Stenmark H, Rybin V, Wilm M, Ashman K, Mann M, Zerial M (1997) A novel Rab5 GDP/GTP exchange factor complexed to Rabaptin-5 links nucleotide exchange to effector recruitment and function. Cell 90: 1149-1159.

[103] Marchese A, Paing MM, Temple BR, Trejo J (2008) G protein-coupled receptor sorting to endosomes and lysosomes. Annu. Rev. Pharmacol. Toxicol. 48: 601-629.

[104] Bright LJ, Kambesis N, Nelson SB, Jeong B, Turkewitz AP (2010) Comprehensive analysis reveals dynamic and evolutionary plasticity of Rab GTPases and membrane traffic in Tetrahymena thermophila. PLoS Genet. 6: 1001155.

[105] Lal K, Field MC, Carlton JM, Warwicker J, Hirt RP (2005) Identification of a very large Rab GTPase family in the parasitic protozoan Trichomonas vaginalis. Mol. Biochem. Parasitol. 143: 226-235.

[106] Turkewitz AP, Bright LJ (2011) A Rab-based view of membrane traffic in the ciliate Tetrahymena thermophila. Small GTPases 2: 222-226.

[107] Saito-Nakano Y, Nakahara T, Nakano K, Nozaki T, Numata O (2010) Marked amplification and diversification of products of ras genes from rat brain, Rab GTPases, in the ciliates Tetrahymena thermophila and Paramecium tetraurelia. J. Eukaryot. Microbiol. 57: 389-99; 
[108] Ramoino P, Usai C, Beltrame F, Fato M, Gallus L, Tagliaferro G, Magrassi R, Diaspro A (2005) GАВАв receptor intracellular trafficking after internalization in Paramecium. Microsc. Res. Tech. 68: 290-295.

[109] Ramoino P, Gallus L, Beltrame F, Diaspro A, Fato M, Rubini P, Stigliani S, Bonanno G, Usai C (2006) Endocytosis of GABAв receptors modulates membrane excitability in the single-celled organism Paramecium. J. Cell Sci. 119: 2056-2064.

[110] Nichols BJ, Lippincott-Schwartz J (2001) Endocytosis without clathrin coats. Trends. Cell Biol. 11: 406-412.

[111] Johannes L, Lamaze C (2002) Clathrin-dependent or not: is it still the question? Traffic 3: 443-451.

[112] Dale LB, Bhattacharya M, Seachrist JL, Anborgh PH, Ferguson SSG (2001) Agoniststimulated and tonic internalization of metabotropic glutamate receptor 1a in human embryonic kidney 293 cells: agonist-stimulated endocytosis is $\beta$-arrestin1 isoformspecific. Mol. Pharmacol. 60: 1243-1253.

[113] Tsao PI, von Zastrow M (2001) Diversity and specifity in the regulated endocytic membrane trafficking of G-protein-coupled receptors. Pharmacol. Ther. 89: 39-147.

[114] Kittler JT, Delmas P, Jovanovic JN, Brown DA, Smart TG, Moss SJ (2000) Constitutive endocytosis of GABAA receptors in association with adaptin AP2 complex modulates inhibitory synaptic currents in hippocampal neurons. J. Neurosci. 20: 7972-7977.

[115] Cinar H, Barnes EM Jr (2001) Clathrin-independent endocytosis of GABA(A) receptors in HEK 293 cells. Biochemistry 40: 14030-14036.

[116] Herring D, Huang R, Singh M, Robinson LC, Dillon GH, Leidenheimer NJ (2003). Constitutive GABAA receptor endocytosis is dynamin-mediated and dependent on a dileucine AP2 adaptin-binding motif within the $\{$ beta\}2 subunit of the receptor. J Biol. Chem. 278: 4046-24052.

[117] Connolly CN, Kittler JT, Thomas P, Uren .M, Brandon NJ, Smart TG, Moss S. J. (1999). Cell surface stability of gamma-aminobutyric acid type A receptors. J. Biol. Chem. 274: 36565-36572.

[118] Nabi IR, Le PH (2003) Caveolae/raft-dependent endocytosis. J. Cell Biol. 161: 673677.

[119] Surmacz L, Wiejak J, Wyroba E (2003) Evolutionary conservancy of the endocytic machinery in the unicellular eukaryote Paramecium. Biol. Cell 95: 69-74.

[120] Surmacz L, Wiejak J, Wyroba E (2006) Cloning of two genes encoding Rab7 in Paramecium. Acta Biochim. Biol. 53: 149-156.

[121] Wyroba E, Surmacz L, Osinska M, Wiejak J (2007) Phagosome maturation in unicellular eukaryote Paramecium: the presence of RILP, Rab7 and LAMP-2 homologues. Eur. J. Histochem. 51: 163-172.

[122] Osinska M, Wiejak J, Wypych E, Bilski H, Bartosiewicz R, Wyroba E (2011) Distinct expression, localization and function of two Rab7 proteins encoded by paralogous genes in a free-living model eukaryote. Acta Biochim. Pol. 58: 597-607.

[123] Manders EM, Verbeek FJ, Aten JA (1993) Measurement of co-localization of objects in dualcolour confocal images. J. Microscopy 169: 375-382. 
[124] Gonzalez RC, Wintz P (1987) Digital Image Processing, $2^{\text {nd }}$ edn., Addison Wesley Publication Company, Mass.USA.

[125] Costes SV, Daelemans D, Cho EH, Dobbin Z, Pavlakis G, Lockett S (2004) Automatic and quantitative measurement of protein-protein colocalization in live cells. Biophys. J. 86: 3993-4003. 